\title{
Why Do Household Portfolio Shares Rise in Wealth?*
}

\author{
Jessica A. Wachter ${ }^{\dagger} \quad$ Motohiro Yogo
}

\begin{abstract}
We develop a life-cycle consumption and portfolio choice model in which households have nonhomothetic utility over two types of goods, basic and luxury. We calibrate the model to match the cross-sectional and life-cycle variation in the basic expenditure share in the Consumer Expenditure Survey. The model explains the degree to which the portfolio share rises in wealth in the cross-section of households in the Survey of Consumer Finances. For a given household, the portfolio share can fall in response to an increase in wealth, even though the model implies decreasing relative risk aversion.
\end{abstract}

(JEL D11, D12, G11)

\footnotetext{
${ }^{*}$ For comments and discussions, we thank Marshall Blume, John Campbell, Francisco Gomes, Urban Jermann, Masao Ogaki, Jonathan Parker, Víctor Ríos-Rull, Raman Uppal, Amir Yaron, Stephen Zeldes, Guofu Zhou, and seminar participants at Nagoya University, Northwestern University, Stanford University, University of California Berkeley, University of Minnesota, University of Pennsylvania, the 2007 Asset Pricing Conference at Washington University in St. Louis, the 2007 Annual Meeting of the Society for Economic Dynamics, and the 2008 Annual Meeting of the American Finance Association. We thank Indraneel Chakraborty for valuable research assistance. This work was supported by a grant from the Rodney L. White Center for Financial Research at the University of Pennsylvania. The views expressed herein are those of the authors and not necessarily those of the Federal Reserve Bank of Minneapolis or the Federal Reserve System. Send correspondence to Motohiro Yogo, Federal Reserve Bank of Minneapolis, Research Department, 90 Hennepin Avenue, Minneapolis, MN 55401-1804; telephone: (612) 204-6476. E-mail: myogo@nber.org.

${ }^{\dagger}$ The Wharton School of the University of Pennsylvania and NBER

${ }^{\ddagger}$ Federal Reserve Bank of Minneapolis and NBER
} 
Surveys of household finances reveal a striking fact: the share of wealth invested in stocks, or risky assets more generally, rises in wealth. While poorer households are less likely to participate in the stock market, this fact alone does not explain the positive relation between wealth and the share of wealth invested in stocks (hereafter, the portfolio share). The portfolio share rises in wealth even among stockholders. While more educated households tend to have higher portfolio shares, the portfolio share rises in wealth even among stockholders with the same education.

This paper examines the role that nonhomothetic utility plays in explaining the observed relation between portfolio choice and wealth. We develop a life-cycle model in which the household consumes two types of goods. The household's utility function has higher curvature over a "basic good" than over a "luxury good". We calibrate and solve the model with a labor-income process that is widely used in the life-cycle literature (e.g., Zeldes, 1989; Carroll, 1997; Gourinchas and Parker, 2002). We then simulate an economy of ex ante identical households who are subject to idiosyncratic income shocks. The model has four main testable predictions for household consumption and portfolio choice.

The first prediction is that the expenditure share falls in total consumption for some goods and rises for others. In the nonhomothetic life-cycle model, households with higher permanent income allocate a lower share of their total consumption to the basic good. Using household consumption data from the Consumer Expenditure Survey, we identify basic goods as those goods whose expenditure shares fall in total consumption. We find a significant relation between the basic expenditure share and total consumption, even within the crosssection of stockholders. We use the variation in the basic expenditure share to guide our calibration of household preferences. Our empirical findings imply significant differences in the utility curvature between basic and luxury goods.

The second prediction is that the portfolio share rises in wealth. In the nonhomothetic life-cycle model, households with higher permanent income are less risk averse, and consequently, allocate a higher share of their wealth to stocks. As in an otherwise similar model 
with homothetic utility, the nonhomothetic life-cycle model implies that the optimal portfolio share falls in wealth, holding constant the level of permanent income. However, such transitory variation in wealth is a less important determinant of portfolio choice than the cross-sectional variation in permanent income, leading to a positive relation between the portfolio share and wealth. We confirm this prediction with household portfolio data from the Survey of Consumer Finances. ${ }^{1}$

The third prediction is that the portfolio share is relatively stable over the life cycle. In the homothetic life-cycle model, the portfolio share falls in age because younger households have greater incentive to diversify their large endowment of non-tradable human capital. Although this incentive also operates in the nonhomothetic life-cycle model, it is offset by a rising life-cycle income profile, which causes risk aversion to fall in age. The nonhomothetic life-cycle model therefore produces a flatter age profile in the portfolio share, which is more consistent with the empirical evidence.

The fourth prediction is that, for a given household, the portfolio share can fall in response to an increase in wealth. In the nonhomothetic life-cycle model, the portfolio share falls in the ratio of wealth to permanent income but rises in permanent income itself. Put differently, the portfolio share falls in response to transitory wealth shocks but rises in response to permanent shocks. Therefore, a regression of changes in the portfolio share onto changes in wealth generates a small negative coefficient in the nonhomothetic life-cycle model, which is consistent with the empirical evidence (Brunnermeier and Nagel, 2008). Our findings suggest that reduced form regressions are unlikely to be able to detect the presence of decreasing relative risk aversion.

We build on an active literature that studies the consumption and portfolio implications of life-cycle models with realistic labor-income processes. One branch of this literature focuses on the life-cycle profile in wealth accumulation and portfolio choice (e.g., Bertaut

\footnotetext{
${ }^{1}$ The fact that the portfolio share rises in wealth has been documented in various household surveys. Early empirical evidence can be found in the 1962 and 1963 Surveys of the Financial Characteristics of Consumers and Changes in Family Finances (Blume and Friend, 1975; Friend and Blume, 1975). Guiso, Haliassos, and Jappelli (2002, Table I.7) contains a summary of the international evidence for five countries.
} 
and Haliassos, 1997; Heaton and Lucas, 1997; Gakidis, 1998; Viceira, 2001; Davis and Willen, 2002; Cocco, Gomes, and Maenhout, 2005). Another branch focuses on the potential role that fixed costs play in explaining non-participation in the stock market. In particular, Cocco (2005), Hu (2005), and Yao and Zhang (2005) find that housing crowds out stocks in the household's portfolio and can explain non-participation in the presence of fixed costs. Gomes and Michaelides (2005) find that low risk aversion, paired with a low elasticity of intertemporal substitution, leads to a low saving motive and can explain non-participation in the presence of fixed costs. Instead of non-participation, we focus on a puzzle that has received relatively little attention: the fact that the portfolio share rises in wealth conditional on participation.

Our work is also related to that of Carroll $(2000,2002)$, who proposes a model in which wealth at the end of life is a luxury good. Carroll's model has the potential to explain the high saving rate and the portfolio behavior of the extremely wealthy (i.e., the top first percentile of the wealth distribution). ${ }^{2}$ Luxury goods also play an important role in the work of Ait-Sahalia, Parker, and Yogo (2004), who develop a representative household model with nonhomothetic utility over two goods. They find that the consumption of luxury goods, constructed from data on the sales of luxury retailers, is consistent with the high historical equity premium. Unlike these previous studies, this paper calibrates and solves a life-cycle model to generate quantitatively testable implications for household consumption and portfolio choice. In addition, while these previous studies have focused on households at the extreme peak of the wealth distribution, our work aims to explain consumption and portfolio choice for the entire cross-section of stockholders.

The remainder of the paper proceeds as follows. Section 1 presents the empirical evidence on household consumption, and Section 2 presents the empirical evidence on household portfolio choice. Section 3 develops a life-cycle model with nonhomothetic utility and describes

\footnotetext{
${ }^{2}$ In related work, Roussanov (2010) develops a model in which the household's preference for social status is effectively a luxury good, which explains why wealthier households own portfolios with undiversified private equity.
} 
the preference and income parameters used in the calibration. Section 4 solves the model and describes the policy functions for consumption and portfolio choice. Section 5 compares the consumption and portfolio behavior of simulated households to that of actual households in the survey data. Section 6 concludes. The appendices contain details on the survey data as well as numerical methods used to solve the life-cycle model.

\section{Evidence on Household Consumption}

\subsection{Consumer Expenditure Survey}

Data on consumption are from the repeated cross-section of U.S. households in the Consumer Expenditure Survey for the period 1982-2003. We focus on the sub-sample of stockholders in all of our analysis. Appendix A contains details on our use of the data, including a description of the relevant categories of nondurable goods and services.

\subsection{Basic versus luxury consumption}

In this section, we use the tools of consumer demand analysis to categorize various nondurable goods and services into basic and luxury goods (Working, 1943; Stone, 1954; Prais and Houthakker, 1955; Leser, 1963). We estimate a censored regression model to characterize the relation between the expenditure share and total consumption for stockholders. The outcome variable is the expenditure share for the various categories of nondurable goods and services. The latent variable depends on age group, log total (nondurable and service) consumption, log total consumption interacted with age group, marital status, household size, and interview-year dummies. The omitted category is households with four members, whose head is aged 46-55 and married. We use consumption instead of wealth as a regressor because consumption data are more complete and reliable than financial data in the Consumer Expenditure Survey. However, we have verified that our main findings are robust to using financial wealth. 
Table 1 reports our results for nondurable goods. For food at home, the coefficient on $\log$ consumption is -8.05 , which shows that its expenditure share falls in total consumption for households aged 46-55. The magnitude of the coefficient means that, for an average household aged $46-55$, a $100 \%$ rise in total consumption is associated with a 8.05 percentage point fall in the expenditure share. The coefficient on the interaction between log consumption and age group is 0.50 for households aged 36-45, which implies a $-8.05+0.50=-7.55$ percentage point change in the expenditure share for a $100 \%$ rise in total consumption. The coefficient on the interaction between log consumption and age group is 0.28 for households aged 56-65. In other words, the negative relation between the expenditure share for food at home and total consumption is weaker for younger and older households, although these differences are not statistically significant.

In contrast to food at home, food away from home as a share of total consumption rises in total consumption within each age group. The fact that the expenditure share rises in total consumption is consistent with introspection, which suggests that dining out frequently is a luxury that mainly wealthier households can afford. Clothing and shoes as a share of total consumption rises in total consumption within each age group. Fuel oil and coal as a share of total consumption falls in total consumption for households aged 46-55, but this relation does not hold for other age groups. Gasoline as a share of total consumption falls in total consumption within each age group. Other nondurable goods as a share of total consumption falls in total consumption within each age group.

Table 2 reports our results for services. Housing as a share of total consumption rises in total consumption within each age group. Household operation as a share of total consumption falls in total consumption within each age group. Transportation as a share of total consumption rises in total consumption within each age group. Personal care as a share of total consumption rises in total consumption for households aged 46-55, but this relation does not hold for other age groups. Personal business (e.g., accounting, banking, and tax services) as a share of total consumption rises in total consumption within each age group. 
Recreation as a share of total consumption rises in total consumption within each age group.

Tables 1 and 2 map out the household Engel curves, that is, the variation in expenditure shares as a function of total consumption. We define basic goods as those categories of nondurable goods and services for which the expenditure share falls in total consumption for all age groups. Luxury goods are those categories of nondurable goods and services for which the expenditure share rises in total consumption for all age groups. Fuel oil and coal and personal care, for which the expenditure share can rise or fall depending on the age group, are excluded from our analysis. Based on these definitions, we construct basic and luxury consumption as the sum of the appropriate categories of expenditure as summarized in Table 3.

\section{Evidence on Household Portfolio Choice}

\subsection{Survey of Consumer Finances}

Data on wealth and portfolio choice are from the repeated cross-section of U.S. households in the Survey of Consumer Finances for the period 1989-2004. Like the Consumer Expenditure Survey, the Survey of Consumer Finances is a nationally representative sample of households. We focus on the sub-sample of stockholders in all of our analysis. Appendix B contains details on our use of the data, including the definitions of net worth, financial assets, risky assets, and public equity.

\subsection{Portfolio share by age and wealth}

We estimate a censored regression model to characterize the relation between the portfolio share and wealth for stockholders. The outcome variable is the portfolio share, defined as the share of net worth invested in risky assets. The latent variable depends on age group,

log net worth, log net worth interacted with age group, marital status, household size, and interview-year dummies. The omitted category is households with four members, whose 
head is aged 46-55 and married.

In our main specification reported in Table 4, the coefficient on log net worth is 3.56, which shows the portfolio share rises in net worth for households aged 46-55. The magnitude of the coefficient means that, for an average household aged 46-55, a $100 \%$ rise in net worth is associated with a 3.56 percentage point rise in the portfolio share. The coefficient on the interaction between log net worth and age group is -1.72 for households aged 36-45, which implies a $3.56-1.72=1.84$ percentage point change in the expenditure share for a $100 \%$ rise in net worth. The coefficient on the interaction between log net worth and age group is 0.32 for households aged 56-65. In other words, the positive relation between the portfolio share and net worth is weaker for younger households and stronger for older households.

As emphasized by Ameriks and Zeldes (2004), the fact that age, time, and cohort effects are not separately identified complicates the interpretation of household portfolio behavior. A common practice in the literature is to interpret the age profile in household portfolios by assuming that there is no cohort effect (e.g., Bertaut and Starr-McCluer, 2002; Campbell, 2006). In our main specification, we follow this practice and analyze the relation between the portfolio share and wealth, controlling for age and interview year. In a second specification reported in Table 4, however, we include cohort dummies instead of interview-year dummies to examine the robustness of our findings. The relation between the portfolio share and net worth is entirely robust to controlling for birth cohort.

Our primary measure of the portfolio share is the share of net worth invested in risky assets. A narrower measure of the portfolio share, sometimes used in the literature, is the share of financial wealth invested in public equity. We focus on the broader measure for a closer correspondence to the portfolio share that enters the intertemporal budget constraint of the life-cycle model. In a third specification reported in Table 4, however, we use the narrower measure of the portfolio share as our outcome variable to examine the robustness of our findings. We still find a statistically significant relation between the portfolio share and net worth. For an average household aged 46-55, a 100\% rise in net worth is associated 
with a $1.58 \%$ rise in the portfolio share.

\subsection{Portfolio share by education}

More educated households tend to be wealthier, and more educated investors tend to have a higher share of their wealth invested stocks (Campbell, 2006). Therefore, the relation between net worth and the portfolio share may be explained, at least partly, by education. To address this issue, Table 5 repeats the analysis in Table 4 separately by education group. The four education groups are households whose head is not a high school graduate, whose head is a high school graduate, whose head has some college education, and whose head is a college graduate. Even after controlling for eduction, there is a strong positive relation between the portfolio share and net worth, comparable to that reported in Table 4.

\section{A Life-Cycle Model of Consumption and Portfolio Choice}

\subsection{Nonhomothetic utility}

Suppose the household consumes two types of nondurable goods, denoted by $B$ and $L$ (for reasons that will become apparent in what follows). We assume that the household's intratemporal utility is given by the additive logarithmic (addilog) function,

$$
V(B, L)=\left(B^{1-\lambda}+\frac{\alpha(1-\lambda)}{1-\phi} L^{1-\phi}\right)^{1 /(1-\lambda)}
$$

where $\alpha \geq 0$ is the utility weight on $L$ (Houthakker, 1960). The curvature parameters satisfy the restriction $\lambda \geq \phi>1$. Although there are many goods and services in practice, the twogood addilog model is a tractable simplification that captures the key features of the data for our application. 
We embed the addilog function in the household's intertemporal utility as

$$
U(B, L)=\frac{V(B, L)^{1-\gamma}}{1-\gamma}
$$

where $\gamma>1$. This specification is a tractable parametric model that permits both nonhomotheticity and non-separability across goods. Since Houthakker (1960), this utility function has been applied in a number of settings to model the fact that as households grow wealthier, they spend relatively more on some goods than on others (e.g., Deaton and Muellbauer, 1980; Ogaki, 1992; Bils and Klenow, 1998; Aït-Sahalia, Parker, and Yogo, 2004; Pakoš, 2004).

The household's consumption allocations are determined entirely by the properties of intratemporal utility. Let $Q$ denote the relative price of $L$ in units of $B$. Optimal relative consumption of the two goods is determined by the first-order condition

$$
\frac{V_{L}}{V_{B}}=\frac{\alpha L^{-\phi}}{B^{-\lambda}}=Q
$$

The elasticity of substitution between the two goods is

$$
\frac{d \log (B /(Q L))}{d \log Q}=\frac{1 / B+1 /(Q L)}{\lambda / B+\phi /(Q L)} .
$$

Let $C=B+Q L$ denote total consumption. The first-order condition (4) implies the expenditure shares

$$
\begin{aligned}
\frac{B}{C} & =\frac{1}{1+\alpha^{1 / \phi} Q^{1-1 / \phi} B^{\lambda / \phi-1}} \\
\frac{Q L}{C} & =\frac{1}{1+\alpha^{-1 / \lambda} Q^{1 / \lambda-1} L^{\phi / \lambda-1}} .
\end{aligned}
$$

The level of expenditure for both $B$ and $L$ rises in total consumption. However, the expenditure share for $B$ falls, and the expenditure share for $L$ rises in total consumption. We therefore refer to $B$ as the "basic good" and $L$ as the "luxury good". 
By substituting the expenditure shares (5) and (6) into utility function (2), we can express household utility as a function of total consumption and the relative price of the luxury good. We denote the so-called indirect utility function as

$$
\begin{aligned}
\widehat{V}(C, Q) & =\max _{B+Q L=C} V(B, L), \\
\widehat{U}(C, Q) & =\frac{\widehat{V}(C, Q)^{1-\gamma}}{1-\gamma} .
\end{aligned}
$$

\subsubsection{Decreasing relative risk aversion}

An important implication of nonhomothetic utility is decreasing relative risk aversion (Stiglitz, 1969). By Hanoch (1977, Theorem 1), we can calculate the household's relative risk aversion as

$$
\begin{aligned}
\mathrm{RRA} & =-\frac{\left(B U_{B}+L U_{L}\right)\left(U_{B B} U_{L L}-U_{B L}^{2}\right)}{U_{B}^{2} U_{L L}-2 U_{B} U_{L} U_{B L}+U_{L}^{2} U_{B B}} \\
& =\left(\frac{1}{\lambda} \frac{B}{C}+\frac{1}{\phi} \frac{Q L}{C}\right)^{-1}\left(B+\frac{1-\lambda}{1-\phi} Q L\right)^{-1}\left(\frac{\gamma}{\lambda} B+\frac{\xi(1-\lambda)}{\phi(1-\phi)} Q L\right),
\end{aligned}
$$

where

$$
\xi=\frac{\gamma(1-\phi)+\phi-\lambda}{1-\lambda}<\gamma
$$

When the household is poor, it consumes mostly basic goods, and its relative risk aversion is close to $\gamma$. As the household becomes wealthier, it consumes more luxury goods, and its relative risk aversion falls toward $\xi$.

\subsubsection{Homothetic utility as a special case}

When $\lambda=\phi$, nonhomothetic utility (1) collapses to the homothetic utility function,

$$
V(B, L)=\left(B^{1-\lambda}+\alpha L^{1-\lambda}\right)^{1 /(1-\lambda)} .
$$


This specification is also referred to as constant elasticity of substitution utility because the elasticity of substitution between the two goods is constant at $1 / \lambda$. The household's indirect utility is

$$
\widehat{V}(C, Q)=C\left(1+\alpha^{1 / \lambda} Q^{1-1 / \lambda}\right)^{1 /(1 / \lambda-1)}
$$

This expression for the indirect utility function shows that the assumption of homotheticity leads to power utility over a composite consumption good, which is the benchmark model in the life-cycle literature. Homothetic utility implies constant relative risk aversion. We calibrate and solve the homothetic life-cycle model to highlight the distinct implications of the nonhomothetic life-cycle model.

\subsection{Life-cycle problem}

We solve a life-cycle consumption and portfolio-choice problem for a household with nonhomothetic utility (2). The household enters each period $t \in[1, T]$ with cash-on-hand $W_{t}$, which consists of financial assets and labor income $Y_{t}$. The household's total consumption is $C_{t}=B_{t}+Q_{t} L_{t}$, which is optimally allocated between basic goods $B_{t}$ and luxury goods $L_{t}$. Wealth remaining after consumption, $S_{t}=W_{t}-B_{t}-Q_{t} L_{t}$, is saved either in bonds or stocks. Bonds have a constant gross rate of return $R_{f}$, and stocks have a stochastic gross rate of return $R_{e, t}$. The household is subject to a borrowing constraint, so that $S_{t} \geq 0$. Following a common assumption in the life-cycle literature, the household is subject to a short-sales constraint, so that the portfolio share must satisfy $a_{t} \in[0,1]$.

The household dies with certainty in period $T+1$, leaving behind cash-on-hand $W_{T+1}$. The household has bequest utility over terminal wealth, $b \widehat{U}\left(W_{T+1}, Q_{T+1}\right)$, where the parameter $b>0$ determines the strength of the bequest motive. We specify the bequest utility to be the same functional form as the household's indirect utility (8), so that the curvature of the utility function is continuous from period $T$ to $T+1$. Therefore, our mechanism is distinct 
from that of Carroll (2002), in which wealth left as a bequest is a luxury good relative to consumption during lifetime.

Let $\beta \in(0,1)$ denote the household's subjective discount factor. The household's problem is to choose consumption and the portfolio share in each period to maximize the expected discounted sum of future utility flow,

$$
\mathbf{E}_{1}\left[\sum_{t=1}^{T} \beta^{t-1} U\left(B_{t}, L_{t}\right)+\beta^{T} b \widehat{U}\left(W_{T+1}, Q_{T+1}\right)\right] .
$$

The household is subject to the intertemporal budget constraint,

$$
\begin{aligned}
& W_{t+1}=R_{t+1}\left(W_{t}-B_{t}-Q_{t} L_{t}\right)+Y_{t+1}, \\
& R_{t+1}=R_{f}+a_{t}\left(R_{e, t+1}-R_{f}\right),
\end{aligned}
$$

in each period $t \in[1, T]$.

\subsection{Calibration of the model}

Following Carroll (1997), we calibrate the model to a 50-year life cycle. The household works and earns labor income from age 26 through 65 (i.e., $t \in[1,40]$ ). The household is retired and earns retirement income from age 66 through 76 (i.e., $t \in[41,51]$ ). At age 76 , the household dies and leaves the remaining wealth as a bequest. Table 6 summarizes the parameters in the benchmark calibration, which we now discuss in more detail.

\subsubsection{Preferences}

For the nonhomothetic life-cycle model, we calibrate the parameters in intratemporal utility (1) to match the basic expenditure share in the Consumer Expenditure Survey. We set $\alpha=2.9$ to match the level of the basic expenditure share for the median household across all age groups. For example, the basic expenditure share is $47 \%$ for households aged $46-55$. 
From equation (4), $\lambda=2.0$ and $\phi=1.1$ determine the elasticity of substitution between the two goods. These parameter values are chosen to match the variation in the basic expenditure share in each age group. For example, the basic expenditure share varies from $57 \%$ for the lowest consumption quartile to $35 \%$ for the highest quartile for households aged $46-55$.

We specify the relative price of the luxury good as

$$
Q_{t}=Q_{t-1} e^{q_{t}},
$$

where we normalize $Q_{1}=1$. We calibrate the growth rate of the relative price as

$$
q_{t}=\left\{\begin{aligned}
-14 \% & \text { for } t \in[2,11] \\
-12 \% & \text { for } t \in[12,21] \\
-10 \% & \text { for } t \in[22,31] \\
-8 \% & \text { for } t \in[32,41] \\
0 \% & \text { for } t \in[42,51]
\end{aligned}\right.
$$

The basic expenditure share rises as the relative price of the luxury good falls because the income effect dominates the substitution effect (see equations (5) and (6)). This specification allows us to match the stable profile of the basic expenditure share over the life cycle, from $47 \%$ for households aged $26-35$ to $51 \%$ for households aged $66-75$. Our model, in which $\alpha$ is constant and $Q$ varies over the life cycle, is isomorphic to one in which $Q$ is constant and $\alpha$ varies over the life cycle. In other words, life-cycle variation in $\alpha$ and $Q$ are not separately identified. Consequently, we treat the relative price of the luxury good as a preference parameter for the purposes of calibration. It can be viewed as a reduced-form way to capture life-cycle effects in preferences, like changes in family composition or employment status over the life cycle.

We set the subjective discount factor to $\beta=0.96$, which is a common choice in the life- 
cycle literature. As shown in equation (9), the relative risk aversion depends on $\gamma$, together with the other preference parameters. We choose the level of risk aversion to match the level of stockholding in the Survey of Consumer Finances. Specifically, given the choices for the other preference parameters described above, $\gamma=45$ matches the portfolio share for the median household aged $46-55$, which is $30 \%$. While our choice comes close to matching the portfolio shares for older households aged 46-75, higher values of $\gamma$ are necessary to explain the low portfolio shares for younger households. Finally, we calibrate the strength of the bequest motive to match the wealth-income ratio for the median household aged 66-75, which is 8.7 .

For the homothetic life-cycle model, we also set the discount factor to $\beta=0.96$. We choose the level of risk aversion, which is $\gamma$ in this model, to match the level of stockholding in the Survey of Consumer Finances. Specifically, we set $\gamma=7$ to match the portfolio share for the median household aged 46-55. Finally, we calibrate the strength of the bequest motive to match the wealth-income ratio for the median household aged 66-75. For simplicity, we assume that the relative price of the luxury good is constant in the homothetic life-cycle model. Even if the relative price were to vary over the life cycle, homotheticity necessarily implies a basic expenditure share that is constant in wealth.

\subsubsection{Labor income}

Following Zeldes (1989) and Carroll (1997), we model the household's stochastic labor income as

$$
\begin{aligned}
& Y_{t}=P_{t} \epsilon_{t}, \\
& P_{t}=G_{t} P_{t-1} \eta_{t},
\end{aligned}
$$

given an initial level $P_{1}$. The variable $P_{t}$ denotes "permanent income" in period $t$, defined as the labor income that would be earned in the absence of transitory shocks (i.e., $\epsilon_{t}=1$ ). 
Permanent income has a deterministic component that grows at the rate $G_{t}$ in each period, which we estimate using the Consumer Expenditure Survey as explained in Appendix A. During the household's working life (through age 65), permanent income is subject to an independently and identically distributed shock

$$
\log \eta_{t} \sim \mathbf{N}\left(-\frac{\sigma_{\eta}^{2}}{2}, \sigma_{\eta}^{2}\right)
$$

where $\mathbf{N}$ denotes the normal distribution. The permanent shock has mean $\mathbf{E}\left[\eta_{t}\right]=1$.

Labor income is also subject to an independently and identically distributed transitory shock

$$
\begin{aligned}
& \epsilon_{t}=\left\{\begin{array}{cc}
0 & \text { with probability } p \\
\widetilde{\epsilon}_{t} & \text { with probability } 1-p
\end{array},\right. \\
& \log \widetilde{\epsilon}_{t} \sim \mathbf{N}\left(\mu_{\epsilon}, \sigma_{\epsilon}^{2}\right) .
\end{aligned}
$$

Unemployment occurs with probability $p$. The parameter $\mu_{\epsilon}$ is chosen so that the transitory shock has mean $\mathbf{E}\left[\epsilon_{t}\right]=1$. In our benchmark case, we set the probability of unemployment to zero so that $\mu_{\epsilon}=-\sigma_{\epsilon}^{2} / 2$ (as in the benchmark calibrations of Cocco, Gomes, and Maenhout, 2005; Gomes and Michaelides, 2005). Following the methodology of Carroll and Samwick (1997), we estimate the variance of the income shocks for the sub-sample of stockholders in the Panel Study of Income Dynamics. Based on the estimates, we calibrate the model so that $\sigma_{\eta}^{2}=1.92 \%$ and $\sigma_{\epsilon}^{2}=3.67 \%$.

During retirement, we assume that labor income is subject to the same transitory shocks as during working life, but is not subject to the permanent shocks. The transitory shocks are meant to capture idiosyncratic risk in retirement, such as medical expenses (Hubbard, Skinner, and Zeldes, 1995). In practice, the transitory shocks make little difference to the results except to make the level of wealth accumulation in retirement higher, which is more consistent with that observed in the Survey of Consumer Finances. 


\subsubsection{Asset returns}

We calibrate asset returns using a common specification in the life-cycle portfolio-choice literature (Gomes and Michaelides, 2005). We set the bond return to $2 \%$ per year and the equity premium to $4 \%$ per year. Stock returns are distributed as

$$
\begin{aligned}
R_{e, t} & =\bar{R}_{e} \nu_{t} \\
\log \nu_{t} & \sim \mathbf{N}\left(-\frac{\sigma_{\nu}^{2}}{2}, \sigma_{\nu}^{2}\right) .
\end{aligned}
$$

The shock to stock returns has mean $\mathbf{E}\left[\nu_{t}\right]=1$ and standard deviation $\sigma_{\nu}=18 \%$. We set the correlation between the shocks to stock returns and permanent income to $\rho=$ $\mathbf{E}\left[\left(\log \nu_{t}\right)\left(\log \eta_{t}\right)\right] /\left(\sigma_{\nu} \sigma_{\eta}\right)=0.15$ (as estimated by Campbell, Cocco, Gomes, and Maenhout, 2001; Gomes and Michaelides, 2005).

\subsection{Discussion of the model}

In our benchmark model, it is always optimal for the household to own some stocks, regardless of the level of wealth. In reality, however, a significant share of the population does not own stocks (Mankiw and Zeldes, 1991; Haliassos and Bertaut, 1995). There are various proposed explanations for non-participation, including fixed costs of participation (Cocco, 2005; Gomes and Michaelides, 2005; Hu, 2005; Yao and Zhang, 2005) and investor mistakes (Calvet, Campbell, and Sodini, 2007). Because non-participation is outside the scope of our study, we interpret our model as a description of stockholders (i.e., those that have already paid the fixed cost and are making optimal decisions). In comparing the model to the data,

we focus on the sub-sample of stockholders in the Consumer Expenditure Survey and the Survey of Consumer Finances.

In modeling household consumption and portfolio choice, we have made several simplifying assumptions. The assumptions allow us to focus on the portfolio implications of the nonhomothetic life-cycle model in the simplest setting. We now discuss two of these assump- 
tions briefly and provide some intuition for how modifications of these assumptions are likely to affect our results.

The first assumption is that households have identical labor income processes. Education is perhaps the most obvious dimension along which there may be income heterogeneity. Carroll and Samwick (1997, Table 1) report the variance of permanent income shocks by education: $2.1 \%$ for some high school, $2.8 \%$ for high school graduates, $2.4 \%$ for some college, $1.5 \%$ for college graduates, and $1.2 \%$ for graduate school. Insofar as education proxies for permanent income, the variance of permanent income shocks appears to fall in the level of permanent income. This empirical evidence favors the nonhomothetic life-cycle model because the homothetic alternative, given these income volatilities, would predict that the volatility of consumption falls in wealth, which seems inconsistent with the empirical evidence (Parker, 2001; Brav, Constantinides, and Geczy, 2002; Vissing-Jørgensen, 2002). In a previous version of this paper, we have calibrated the model separately by education group to verify that income heterogeneity is not critical for our results.

The second assumption is that expected stock returns are constant. A time-varying investment opportunity set can generate life-cycle patterns in stock ownership, but it is unlikely to affect the relation between the portfolio share and wealth that is the focus of this paper. For this line of work, we refer to Kim and Omberg (1996), Balduzzi and Lynch (1999), Campbell and Viceira (1999), Barberis (2000), and Wachter (2002).

\section{Solution of the Life-Cycle Model}

We solve the life-cycle problem through numerical dynamic programming as described in Appendix C. As shown in the appendix, the household's value function can be written as a function of age $(t)$, normalized cash-on-hand $\left(w_{t}=W_{t} / P_{t}\right)$, and permanent income $\left(P_{t}\right)$. This section describes the optimal policies for consumption and portfolio choice. 


\subsection{Optimal consumption policy}

Figure 1 shows the optimal consumption policy, as a function of normalized cash-on-hand and permanent income, for the household at age 50. The policy variables are basic consumption and luxury consumption, both of which are expressed in units of basic consumption and normalized by permanent income. At a fixed level of permanent income, the consumption function for both basic and luxury goods share the two key features of the consumption function in the homothetic life-cycle model. First, both functions are monotonically increasing in cash-on-hand. Second, both functions are concave in cash-on-hand.

At a fixed level of normalized cash-on-hand, basic consumption falls more than proportionally with permanent income, and luxury consumption rises more than proportionally with permanent income. At a low level of permanent income, basic consumption rises rapidly in normalized cash-on-hand, while luxury consumption rises only gradually in normalized cash-on-hand. Put differently, the marginal propensity to consume the basic good is high, while the marginal propensity to consume the luxury good is low. However, the marginal propensity to consume the luxury good rises more rapidly in permanent income than does the marginal propensity to consume the basic good. At a sufficiently high level of permanent income, the luxury good becomes the more responsive of the two goods to cash-on-hand.

\subsection{Optimal portfolio policy}

Figure 2 shows the optimal portfolio policy, as a function of normalized cash-on-hand and permanent income, for the household at age 50. At a fixed level of permanent income, the portfolio share falls in cash-on-hand. Because labor income is relatively stable and has a low correlation with stock returns, human capital is nearly a substitute for bonds. The lower is cash-on-hand relative to permanent income, the higher is the implicit allocation to bonds as a share of total wealth (i.e., the sum of financial wealth and human capital). Therefore, the lower is normalized cash-on-hand, the higher is the optimal allocation to stocks as a share of financial wealth. This effect is also present in the homothetic life-cycle model (Bodie, 
Merton, and Samuelson, 1992).

At a fixed level of normalized cash-on-hand, higher permanent income leads to lower risk aversion under nonhomothetic utility. Consequently, the household allocates a higher share of wealth to stocks at a higher level of permanent income. At a low level of permanent income, the household allocates a high share of total consumption to the basic good, and it resembles a power-utility investor with high risk aversion $\gamma$. At a high level of permanent income, the household allocates a high share of total consumption to the luxury good, and it resembles a power-utility investor with low risk aversion $\xi$.

In summary, the model predicts that there are two offsetting effects of wealth on portfolio choice, one that operates through cash-on-hand and another that operates through permanent income. In the next section, we simulate the model to understand the interaction of these two effects.

\section{Simulation of the Life-Cycle Model}

In order to assess the quantitative implications of the model, we simulate a cross-section of 10,000 households at an annual frequency. The households are ex ante identical, have nonhomothetic utility, and face non-tradable labor income. Table 6 summarizes the preference and income parameters of the model. In order to highlight the novel implications of the nonhomothetic life-cycle model, we repeat the same simulation exercise for the homothetic life-cycle model.

For each household, we draw an initial level of wealth (relative to permanent income) from a lognormal distribution. Based on estimates for the sub-sample of stockholders in the Survey of Consumer Finances, we set the mean of $W_{1} / P_{1}$ to 0.988 and the standard deviation of its logarithm to 1.370. Similarly, we draw an initial level of permanent income from a lognormal distribution. Based on estimates for the sub-sample of stockholders in the Consumer Expenditure Survey, we normalize the mean of $P_{1}$ to one and set the standard 
deviation of its logarithm to 0.512 .

\subsection{Implications for consumption}

Panel A of Table 7 reports the basic expenditure share for stockholders in the Consumer Expenditure Survey, tabulated by age group and consumption quartile. To create the table, we first sort households into age groups of ten years, based on the age of the household head. Within each age group and interview year, we then sort households into quartiles based on their total consumption. ${ }^{3}$ For each age group, we create an additional bin for households whose consumption is in the top fifth percentile, in order to separately analyze the behavior of the wealthy. The last row of the panel reports statistics for all households in that age group.

For households aged 36-45, basic consumption is $59 \%$ of total consumption for the lowest consumption quartile and $38 \%$ for the highest quartile. The basic expenditure share is $30 \%$ for households in the top fifth percentile of total consumption. For households aged 56-65, basic consumption is $60 \%$ of total consumption for the lowest consumption quartile and $34 \%$ for the highest quartile. The basic expenditure share is $28 \%$ for households in the top fifth percentile of total consumption. The small standard errors indicate that there is virtually no sampling uncertainty around these point estimates.

In Panel B, we sort households simulated in the nonhomothetic life-cycle model into age groups, then into quartiles of consumption within each age group. We then tabulate the median of the basic expenditure share within each bin and compare the results with the empirical moments in Panel A. Within each age group, the basic expenditure share falls in total consumption, essentially matching the empirical moments. For households aged 36-45, basic consumption is $58 \%$ of total consumption for the lowest consumption quartile and $35 \%$

\footnotetext{
${ }^{3}$ In comparing the level of consumption across households, we control for household characteristics, using a procedure similar to that in Carroll and Samwick (1997) and Gourinchas and Parker (2002). We regress log consumption on a set of dummy variables for marital status and household size. For each household, we use the estimated coefficients to compute the equivalence scale for a household with four members, whose head is married.
} 
for the highest quartile. The basic expenditure share is $30 \%$ for households in the top fifth percentile of total consumption. For households aged 56-65, basic consumption is $62 \%$ of total consumption for the lowest consumption quartile and $36 \%$ for the highest quartile. The basic expenditure share is $31 \%$ for households in the top fifth percentile of total consumption.

These results can be explained by the shape of the consumption policy functions in Figure 1. As households become wealthier, their consumption of the luxury good (i.e., the good with the lower curvature) rises relative to their consumption of the basic good (i.e., the good with the higher curvature). Therefore, the basic expenditure share falls in wealth in the nonhomothetic life-cycle model, in contrast to the homothetic life-cycle model in which the expenditure share is constant.

\subsection{Implications for portfolio choice}

We now examine the implications of our model for portfolio choice. Specifically, we examine the portfolio share by wealth, the portfolio share by age, and the response of the portfolio share to changes in wealth.

\subsubsection{Portfolio share by wealth}

Panel A of Table 8 reports the median portfolio share for stockholders in the Survey of Consumer Finances, tabulated by age group and wealth quartile. For households aged 3645 , the portfolio share is $23 \%$ for the lowest wealth quartile and $44 \%$ for the highest quartile. The portfolio share is $67 \%$ for households in the top fifth percentile of net worth. For households aged 56-65, the portfolio share is $18 \%$ for the lowest wealth quartile and $47 \%$ for the highest quartile. The portfolio share is $65 \%$ for households in the top fifth percentile of net worth. The small standard errors indicate that there is virtually no sampling uncertainty around these point estimates.

Panel B reports the portfolio share for households simulated in the nonhomothetic lifecycle model. The portfolio share rises in wealth for all but the youngest households, broadly 
consistent with the empirical evidence in Panel A. For households aged 36-45, the portfolio share is $29 \%$ for the lowest wealth quartile and $42 \%$ for the highest quartile. The portfolio share is $44 \%$ for households in the top fifth percentile of wealth. For households aged 56-65, the portfolio share is $17 \%$ for the lowest wealth quartile and $34 \%$ for the highest quartile. The portfolio share is $36 \%$ for households in the top fifth percentile of wealth.

As discussed in Section 4, there are two offsetting effects that determine the relation between the portfolio share and wealth in the nonhomothetic life-cycle model. On the one hand, households with higher wealth have higher normalized cash-on-hand (i.e., the ratio of cash-on-hand to permanent income), holding constant the level of permanent income. On the other hand, higher wealth implies higher permanent income, holding constant the level of normalized cash-on-hand. With the exception of the youngest households, the latter effect dominates so that overall there is a positive relation between the portfolio share and wealth. As households age and accumulate permanent income shocks, the cross-sectional variation in permanent income rises. This effect explains why the difference in the portfolio share between high and low wealth households becomes more pronounced from youth to middle age.

Panel C reports the portfolio share for households simulated in the homothetic lifecycle model, which provides a useful contrast to the nonhomothetic life-cycle model. For households aged $36-45$, the portfolio share falls in wealth from $47 \%$ for the lowest wealth quartile to $40 \%$ for the highest quartile. For households aged $46-55$, the portfolio share is flat in wealth. For households aged 56-65, the portfolio share rises slightly in wealth from $26 \%$ for the lowest wealth quartile to $28 \%$ for the highest quartile.

In the homothetic life-cycle model, normalized cash-on-hand is the single state variable that determines portfolio choice. As discussed in Section 4, the portfolio share falls in normalized cash-on-hand. Recall that cash-on-hand is wealth plus current labor income. Therefore, it is not surprising that the portfolio share falls in wealth for younger households aged 26-45. What is perhaps more surprising is that the portfolio share is flat or rising for 
older households. This is driven by the fact that as households accumulate more wealth, cash-on-hand and permanent income become positively related. Therefore, households with higher cash-on-hand may in fact have lower normalized cash-on-hand, and therefore a higher portfolio share. Shim (2009) also describes this effect and emphasizes its dependence on the persistence of labor income shocks. While this effect can produce a pattern for the portfolio share that is qualitatively consistent with the data, the magnitude of the effect is small. This effect is also present in the nonhomothetic model and may contribute to the positive relation between portfolio share and wealth for older households. In the nonhomothetic model, however, this effect is greatly enhanced by the direct effect of permanent income on portfolio choice.

\subsubsection{Portfolio share by age}

As shown in Panel A of Table 8, the portfolio share in the Survey of Consumer Finances has a slight hump-shaped age profile (Ameriks and Zeldes, 2004). An implication of the homothetic life-cycle model is that the portfolio share falls in age, which is inconsistent with the empirical evidence (Cocco, Gomes, and Maenhout, 2005). Households are born with little wealth, but a large stake in non-tradable human capital. Because stocks have a high average rate of return and low correlation with labor income, optimal portfolio allocation requires that households initially allocate most of their wealth to stocks. As households age, they accumulate wealth and decumulate their human capital. The portfolio share consequently falls because there is less need to diversify human capital.

In the nonhomothetic life-cycle model, this age effect in portfolio choice is offset by the fact that households become less risk averse as their permanent income grows over the life cycle. Panel B shows that the median portfolio share gradually falls in the nonhomothetic life-cycle model, from $63 \%$ for households aged 26-35 to $25 \%$ for households aged 56-65. We find that decreasing relative risk aversion alone cannot fully explain the high portfolio share for the youngest households. In contrast, Panel $\mathrm{C}$ shows that the median portfolio share 
falls more strongly in the homothetic life-cycle model, from $90 \%$ for households aged 26-35 to $27 \%$ for households aged $56-65$.

The literature has proposed other compelling explanations for the discrepancy between the life-cycle implications of the homothetic life-cycle model and the data. First, the true relation between age and the portfolio share is unknown because of the lack of identification between age, time, and cohort effects (Ameriks and Zeldes, 2004). Second, the purchase of housing and small fixed costs can crowd out stocks from the household's portfolio early in life (Cocco, 2005; Hu, 2005; Yao and Zhang, 2005). Third, internal habit formation can induce a strong motive to save in bonds early in life, crowding out stocks from the household's portfolio (Gomes and Michaelides, 2003; Polkovnichenko, 2007). Finally, different assumptions about the joint process for stock returns and labor income can substantially reduce stockholding for younger households (Benzoni, Collin-Dufresne, and Goldstein, 2007; Storesletten, Telmer, and Yaron, 2007; Lynch and Tan, 2010).

\subsubsection{Response of the portfolio share to changes in wealth}

In recent work, Brunnermeier and Nagel (2008) use data from the Panel Study of Income Dynamics and find that the portfolio share falls slightly (or changes very little) in response to an increase in wealth. Their findings may initially appear to be evidence against decreasing relative risk aversion, and therefore, evidence against the nonhomothetic life-cycle model. In this section, we show that their findings are entirely consistent with our model.

Using data simulated in the nonhomothetic life-cycle model, we estimate a cross-sectional regression model. We obtain the estimates

$$
100\left(a_{t}-a_{t-1}\right)=-0.9-7.5 \log \left(\frac{S_{t}}{S_{t-1}}\right)+e_{t}
$$

where $a_{t}$ is the portfolio share and $S_{t}$ is wealth in period $t$. (The portfolio share has been

multiplied by 100 in the regression so that its units are percentage points.) The coefficient 
on the change in wealth is -7.5 , which implies that a $10 \%$ increase in wealth leads to a 0.75 percentage point fall in the portfolio share. The regression model reported here is estimated on a pooled sample of households across all age groups, but we obtain similar results when we estimate the model separately by age. Importantly, the coefficient produced by our model is the same sign and order of magnitude as that reported in Brunnermeier and Nagel (2008, Table 4).

In the absence of labor income, Brunnermeier and Nagel hypothesize that models with decreasing relative risk aversion imply that the portfolio share should rise in response to an increase in wealth. In the presence of labor income, however, models with decreasing relative risk aversion imply that the portfolio share can fall in response to an increase in wealth. This is evident in Figure 2, which shows that the optimal portfolio share falls in normalized cash-on-hand and rises in permanent income. To clarify this point, we now add consumption growth to the cross-sectional regression model. We obtain the estimates

$$
100\left(a_{t}-a_{t-1}\right)=-0.8-12.6 \log \left(\frac{S_{t}}{S_{t-1}}\right)+10.6 \log \left(\frac{C_{t}}{C_{t-1}}\right)+e_{t}
$$

where $C_{t}$ is consumption in period $t$. The coefficients of the regression show that the portfolio share falls in response to a positive wealth shock, holding constant consumption growth which proxies for the change in permanent income.

Our findings here have practical implications for empirical work. Cross-sectional regressions, such as equation (25), are not useful for detecting the presence of decreasing relative risk aversion. In the life-cycle model, the portfolio share rises only in response to permanent wealth shocks, not in response to transitory shocks. One way to isolate permanent changes in wealth is to include consumption growth in the regression, as in equation (26). In practice, however, this is difficult because data sets with consumption, such as the Consumer Expenditure Survey and the Panel Study of Income Dynamics, have poor or incomplete data on wealth. Conversely, data sets with wealth, such as the Survey of Consumer Finances, 
have no consumption data.

\subsection{Portfolio choice with unemployment risk}

We now examine how unemployment risk, modeled as a positive probability of zero income, affects portfolio choice. The possibility of zero income can cause the optimal portfolio share to rise in cash-on-hand at a sufficiently low level of wealth, even under power utility (Cocco, Gomes, and Maenhout, 2005). The parameters of the model remain the same as those in Table 6, except that labor income can be zero in any period of the working life with probability $0.5 \%$ (Carroll, 1992). This scenario is potentially extreme because an unemployed household may have other sources of income such as unemployment benefits and social welfare (Gakidis, 1998). This scenario should therefore be interpreted as a robustness check that leads to maximum contrast to our benchmark case with no unemployment.

Because the results for consumption are nearly identical to those in the benchmark case with no unemployment, we focus on the results for portfolio choice in this section. Panel A of Table 8 reports the median portfolio share for stockholders in the Survey of Consumer Finances for the purposes of comparison to the models. Panel B reports the portfolio share in the nonhomothetic life-cycle model, and Panel $\mathrm{C}$ reports the portfolio share in the homothetic life-cycle model. Unemployment risk lowers the portfolio share for the youngest households, especially for those in the lowest wealth quartile. However, unemployment risk hardly affects older households who have accumulated enough wealth to buffer these transitory shocks to labor income.

Given the preference and income parameters that have realistic implications for household saving behavior, unemployment risk does not have a significant effect on portfolio choice for most households. Distributional assumptions that lead to more dependence between stock returns and labor income can have a similar effect to unemployment risk, that is, the portfolio share can rise in cash-on-hand at a sufficiently low level of wealth (Benzoni, Collin-Dufresne, and Goldstein, 2007; Lynch and Tan, 2010). However, this effect disappears in age and should 
be nonexistent for retired households with no labor income. Therefore, it cannot explain the fact that the relation between the portfolio share and wealth persists as households age.

\subsection{Implications for asset pricing}

Although the focus of this paper is portfolio choice, our model has important implications for asset pricing that are also consistent with the empirical evidence. A recent and growing literature in asset pricing proposes heterogeneity in risk aversion as an explanation for a number of facts that are puzzling from the point of view of the benchmark model (i.e., representative household with constant relative risk aversion).

One branch of the literature is motivated by the observation that the consumption Euler equation need not hold for a representative household because only a sub-sample of the population actually own stock (Mankiw and Zeldes, 1991). Moreover, markets may be incomplete or risk aversion may be heterogeneous within the sub-sample of stockholders. Parker (2001) and Brav, Constantinides, and Geczy (2002) estimate the Euler equation with excess stock returns, separately for stockholders in the Consumer Expenditure Survey at different levels of wealth. They find some evidence that the level of risk aversion necessary to account for the joint time-series behavior of consumption and stock returns is lower for wealthier households. This finding is based on the fact that both the variance of consumption growth and the covariance of consumption growth with stock returns rises in wealth within the subsample of stockholders. ${ }^{4}$ Brav, Constantinides, and Geczy (2002) and Malloy, Moskowitz, and Vissing-Jørgensen (2009) show a similar result for excess returns on value stocks over growth stocks as well as small-cap stocks over large-cap stocks.

Another branch of the literature analyzes general equilibrium economies in which households have heterogeneous risk aversion. Chan and Kogan (2002) and Gârleanu and Panageas (2008) show that heterogeneity in risk aversion leads to countercyclical variation in the price

\footnotetext{
${ }^{4}$ At the extreme upper tail of the wealth distribution not represented in the Consumer Expenditure Survey, Ait-Sahalia, Parker, and Yogo (2004) find that the consumption of luxury goods, constructed from data on the sales of luxury retailers, has an even higher covariance with stock returns.
} 
of risk, through endogenous changes in the cross-sectional distribution of wealth. These models offer quantitative explanations for important asset-pricing facts such as the high equity premium, the volatility of stock returns, and the countercyclical variation in the equity premium.

The asset-pricing literature discussed above takes heterogeneity in risk aversion as exogenous. Our model endogenizes such heterogeneity in an economy of ex ante identical households with nonhomothetic preferences, subject to idiosyncratic income shocks over the life cycle. We thus provide a parsimonious explanation for heterogeneity in risk aversion; wealthier households consume more luxury goods and are therefore more tolerant of uncertainty in their consumption stream. Our model is consistent with those asset-pricing facts that can be explained by heterogeneity in risk aversion. Moreover, our model is consistent with the empirical evidence on household consumption and portfolio choice as this paper has shown.

In addition to cross-sectional heterogeneity in risk aversion, our model also implies that risk aversion varies over time for individual households. Our model implies that individual households become more risk averse when their wealth decreases. Consequently, the household's intertemporal marginal rate of substitution is more volatile and has higher negative covariance with stock returns, compared to the benchmark model with constant relative risk aversion. This precise mechanism has been exploited in a representative household context to explain important asset-pricing facts, most notably by Campbell and Cochrane (1999). In a similar line of work, Pakoš (2004) and Lochstoer (2009) explain the asset-pricing facts in a two-good model with luxury goods, building on the work of Aitt-Sahalia, Parker, and Yogo (2004). We suspect that time-varying risk aversion would magnify the effects of heterogeneity in risk aversion demonstrated by the studies discussed above, making it easier to explain the asset-pricing facts. 


\section{Conclusion}

Household surveys of consumption and wealth have uncovered numerous facts that are inconsistent with the life-cycle consumption and portfolio choice model with homothetic utility.

1. The expenditure share for various categories of nondurable goods and services vary significantly in total consumption.

2. The portfolio share rises in wealth, even after controlling for stock market participation and education.

3. The portfolio share is relatively stable in age.

4. The portfolio share falls slightly (or changes very little) in response to an increase in wealth (Brunnermeier and Nagel, 2008).

In this paper, we propose a simple and parsimonious explanation for the observed crosssectional variation in consumption and portfolio behavior. Our only departure from previous life-cycle models is that the household has nonhomothetic utility over two types of consumption goods. Nonhomothetic utility has a long tradition in microeconomic studies of consumer behavior, but there has been little application in life-cycle models of consumption and portfolio choice. We calibrate the model with a widely used labor-income process that has low correlation with stock returns. We find that the nonhomothetic life-cycle model quantitatively explains all four of these facts on household consumption and portfolio choice. 


\section{Appendix A. Consumer Expenditure Survey}

The Bureau of Labor Statistics collects data on household characteristics, major expenditures, and income in the Interview Survey component of the Consumer Expenditure Survey. The Bureau of Labor Statistics uses a national probability sample of households, designed to represent the total noninstitutional civilian population. The survey is a rotating panel of approximately 5,000 households every calendar quarter (rising to 7,000 households more recently). The Bureau of Labor Statistics interviews each household up to five times every three months before replacement. The first interview is for practice, so that only the second through fifth interviews are available in the public-use data files. The Bureau of Labor Statistics interviews approximately the same number of households in each of the three months of a calendar quarter, and households report their expenditures from the previous three months at each interview. Therefore, the survey can be thought of as three non-overlapping panels of quarterly expenditure data. We use the consumer unit replicate weight (FINLWT21) to weight households in all of our analysis, although the results are not at all sensitive to the use of the sample weight.

We use all data files from 1982 through 2003. We do not use data files from 1980 and 1981 because the expenditure on food was collected with a different questionnaire. The Bureau of Labor Statistics has changed the sampling design of the Consumer Expenditure Survey on two occasions, between 1985 and 1986 and between 1995 and 1996. Consequently, households cannot be linked across data files during these years. Therefore, households in the 1985:4 interview are linked to the same households in the early release of 1986:1 interview from the 1985 data files. Similarly, we use the early release of 1996:1 interview from the 1995 data files.

Following a common procedure in the literature (Attanasio and Weber, 1995), we drop households that live in rural areas, live in student housing, or are incomplete income respondents. We drop rural households because the Bureau of Labor Statistics failed to interview them during 1981:3-1983:4. We use the Member Characteristics and Income File to identify 
the reference person of each household and, for married households, the spouse. We define the household head as the husband for married households and as the reference person otherwise. Only households whose head is between age 26 and 75 at the time of interview are kept for analysis. Households are grouped by birth cohort and education based on the characteristics of the household head. We create 13 birth cohorts in five-year bins, from those born 1910-1914 to those born 1975-1979. The four education groups are some high school, high school graduate, some college, and college graduate.

We construct household consumption using the Monthly Expenditures File. The Bureau of Labor Statistics estimates that approximately 90-95\% of total household expenditures are covered by the survey. We focus on the consumption of nondurable goods and services for the following major categories of expenditure.

- Nondurable goods: Food at home, food away from home, clothing and shoes, gasoline, fuel oil and coal, and other nondurable goods. ${ }^{5}$

- Services: Housing, household operation, transportation, personal care, personal business, and recreation.

We exclude durable goods (such as "motor vehicles and parts" and "furniture and household equipment"), health, and education from our measure of consumption. Because the Consumer Expenditure Survey reports only expenditures, the service flow from durable goods cannot be reliably measured based on the data available. For housing, however, we can impute its service flow and therefore include it in our measure of consumption. Housing consumption is the rent paid plus the cost of materials and services for maintenance. For households that own their home, the Consumer Expenditure Survey reports "the rental equivalence of owned home", which we use as our measure of rent.

Our unit of analysis is annual consumption so that each household accounts for one observation in the data set. To eliminate obvious data errors, we drop households that report

\footnotetext{
${ }^{5}$ Other nondurable goods includes semidurable house furnishings, cleaning and polishing preparations, and nondurable toys and sport supplies.
} 
no food or only food expenditures in a given month. Monthly expenditures are summed over all three months of an interview period, which yields total household consumption for that quarter. We deflate nominal expenditures to real 2001 dollars using the consumer price index for all urban consumers. Each expenditure item in the Consumer Expenditure Survey is carefully matched to a region- and item-specific consumer price index, so that the price deflator is household specific.

In the second and fifth interviews, the Bureau of Labor Statistics collects income data for the previous twelve months. We compute disposable income as total household income after taxes minus capital income and pension contributions. Capital income includes interest on savings accounts and bonds as well as income from dividends, royalties, estates, and trusts. Pension contributions is the sum of income contributed to Social Security, railroad retirement, government retirement, private pension, and individual retirement plans.

Following Gourinchas and Parker (2002), we estimate average life-cycle income to calibrate the deterministic growth rate of permanent income. We regress log disposable income on a third degree polynomial in age, which is interacted with a dummy variable for whether or not the household is retired. The regression also includes dummy variables for marital status, household size, and birth cohort. We use the estimated coefficients to build the life-cycle income profile for a "typical" household that works from age 26 through 65 and is retired from age 66 through 75 . At retirement, labor income is estimated to fall by $31 \%$ relative to the previous period. We calibrate the model using the estimated growth rate for a household with four members, whose head is born in the 1945-1949 cohort and married.

In the fifth interview, the Bureau of Labor Statistics collects financial data for the previous twelve months. In particular, households report the estimated value of securities such as stocks, mutual funds, private bonds, and Treasury notes. Following Vissing-Jørgensen (2002), a household is identified as a stockholder if its holding in these securities was positive twelve months prior to the interview or has increased in the previous twelve months. 


\section{Appendix B. Survey of Consumer Finances}

The Board of Governors of the Federal Reserve System conducts the Survey of Consumer Finances every three years based on a dual-frame sample design. They select one sample based on a standard multistage area-probability design, which leads to a representative sample of approximately 3,000 households. They select a second sample based on tax data from the Statistics of Income Division of the Internal Revenue Service, which leads to a representative sample of approximately 1,500 high-wealth households. The survey provides sample weights for adjusting biases caused by missing responses and for calculating aggregate statistics that are representative of the whole population. We use the sample replicate weight (WGT) to weight households in all of our analysis. Aizcorbe, Kennickell, and Moore (2003) and references therein describe the sampling methodology in further detail.

Because the data are available in the present format since 1989, we use all data files from 1989 through 2004. Most of our variables are from the extract file of the full public data set, available in Excel format from the Board of Governors's Survey of Consumer Finances website. For the construction of the value of risky bonds, however, we use variables from the full public data set. Only households whose head is between age 26 and 75 at the time of interview are kept for analysis. We exclude households with non-positive net worth as well as those with no risky-asset holdings from the sample. We deflate nominal wealth to real 2001 dollars using the September value of the consumer price index for all urban consumers.

We now define various components of wealth that are relevant for our analysis. The variable names that follow refer to those from the Survey of Consumer Finances codebook. Net worth (NETWORTH) is the sum of financial and nonfinancial assets minus all debt. Financial assets include liquid financial accounts; certificates of deposit; directly held bonds and stocks; mutual funds; retirement (both individual and employer-sponsored thrift-type) accounts; the cash value of life insurance; and equity interest in trusts, annuities, and managed investment accounts. Nonfinancial assets include the primary residence, investment real estate, and business equity. Debt includes mortgage and home equity loans for primary 
residence and investment real estate, credit card balances, and other loans.

Risky assets is the sum of public equity (EQUITY), investment real estate (NNRESRE), business equity (BUS), and risky bonds (following Bertaut and Starr-McCluer, 2002, Table 5.7). Public equity includes both directly held stock and stocks held through mutual funds, retirement accounts, trusts, and other managed investment accounts. Investment real estate includes residential and nonresidential property that is not primary residence and not owned through a business. Business equity is net equity in all types of privately owned businesses, farms or ranches, professional practices, and partnerships. Risky bonds is the sum of corporate bonds (X7634), foreign bonds (X7633), and mortgage-backed bonds (X3906).

\section{Appendix C. Numerical Solution of the Life-Cycle Model}

Following the usual methodology, we solve the model backward from the last period of life. In order to define the bequest function, we compute the optimal consumption policy for a given level of cash-on-hand in the last period:

$$
\begin{aligned}
B_{T+1} & =\frac{W_{T+1}}{1+\alpha^{1 / \phi} Q_{T+1}^{1-1 / \phi} B_{T+1}^{\lambda / \phi-1}}, \\
L_{T+1} & =\frac{W_{T+1}}{1+\alpha^{-1 / \lambda} Q_{T+1}^{1 / \lambda-1} L_{T+1}^{\phi / \lambda-1}} .
\end{aligned}
$$

The value function in period $T$ is given by

$$
J_{T}\left(W_{T}, P_{T}\right)=\max _{B_{T}, L_{T}, a_{T}}\left\{U\left(B_{T}, L_{T}\right)+\beta \mathbf{E}_{T}\left[b U\left(B_{T+1}, L_{T+1}\right)\right]\right\} .
$$

We normalize the consumption policy variables by permanent income as $b_{t}=B_{t} / P_{t}$ and $l_{t}=L_{t} / P_{t}$. Similarly, we normalize cash-on-hand as $w_{t}=W_{t} / P_{t}$ and wealth as $s_{t}=$ 
$w_{t}-b_{t}-Q_{t} l_{t}$. Finally, we define the recursive function

$$
j_{t}\left(w_{t}, P_{t}\right)=\max _{b_{t}, l_{t}, a_{t}}\left\{u_{t}\left(b_{t}, l_{t}\right)+\beta \mathbf{E}_{t}\left[\left(G_{t+1} \eta_{t+1}\right)^{1-\gamma} j_{t+1}\left(w_{t+1}, P_{t+1}\right)\right]\right\},
$$

where

$$
u_{t}\left(b_{t}, l_{t}\right)=\frac{1}{1-\gamma}\left(b_{t}^{1-\lambda}+\frac{\alpha(1-\lambda)}{1-\phi} P_{t}^{\lambda-\phi} l_{t}^{1-\phi}\right)^{(1-\gamma) /(1-\lambda)} .
$$

The value function in period $T$ can be rewritten as

$$
J_{T}\left(W_{T}, P_{T}\right)=P_{T}^{1-\gamma} j_{T}\left(w_{T}, P_{T}\right)
$$

By induction, the value function in any period $t \leq T$ is given by

$$
J_{t}\left(W_{t}, P_{t}\right)=P_{t}^{1-\gamma} j_{t}\left(w_{t}, P_{t}\right)
$$

We redefine the life-cycle problem as the solution to Bellman equation (C4) subject to the intertemporal budget constraint,

$$
w_{t+1}=\frac{R_{t+1} s_{t}}{G_{t+1} \eta_{t+1}}+\epsilon_{t+1},
$$

and the law of motion for permanent income (19). The first-order conditions with respect to basic consumption $\left(b_{t}\right)$ and the portfolio share $\left(a_{t}\right)$, together with the envelope theorem, imply that

$$
\begin{aligned}
u_{b t} & =\mathbf{E}_{t}\left[\beta R_{t+1}\left(G_{t+1} \eta_{t+1}\right)^{-\gamma} u_{b, t+1}\right], \\
0 & =\mathbf{E}_{t}\left[\beta s_{t}\left(R_{e, t+1}-R_{f}\right)\left(G_{t+1} \eta_{t+1}\right)^{-\gamma} u_{b, t+1}\right],
\end{aligned}
$$


where

$$
u_{b t}=b_{t}^{-\gamma}\left(1+\frac{\alpha(1-\lambda)}{1-\phi} P_{t}^{\lambda-\phi} \frac{l_{t}^{1-\phi}}{b_{t}^{1-\lambda}}\right)^{(\lambda-\gamma) /(1-\lambda)}
$$

The life-cycle problem is essentially solved through recursion on these equations.

We discretize the joint probability distribution for stock returns and income shocks as

$$
\begin{aligned}
&\left\{\left(\nu_{i}, p_{\nu, i}\right)\right\}_{i=1}^{I}=\left\{\left(\nu_{1}, p_{\nu, 1}\right), \ldots,\left(\nu_{I}, p_{\nu, I}\right)\right\}, \\
&\left\{\left(\eta_{j}, p_{\eta, j}\right)\right\}_{j=1}^{J}=\left\{\left(\eta_{1}, p_{\eta, 1}\right), \ldots,\left(\eta_{J}, p_{\eta, J}\right)\right\} \\
&\left\{\left(\epsilon_{k}, p_{\epsilon, k}\right)\right\}_{k=1}^{K}=\left\{\left(\epsilon_{1}, p_{\epsilon, 1}\right), \ldots,\left(\epsilon_{K}, p_{\epsilon, K}\right)\right\}
\end{aligned}
$$

We use a multinomial approximation to the normal distribution with $I=J=K=10$, so that each grid point occurs with equal probability. We discretize wealth after consumpion as

$$
\left\{s_{l}\right\}_{l=1}^{L}=\left\{s_{1}, \ldots, s_{L}\right\}
$$

Similarly, we discretize the state variables as

$$
\begin{gathered}
\left\{w_{m}\right\}_{m=1}^{M}=\left\{w_{1}, \ldots, w_{M}\right\}, \\
\left\{P_{n}\right\}_{n=1}^{N}=\left\{P_{1}, \ldots, P_{N}\right\} .
\end{gathered}
$$

We space the grid points equally on a logarithmic scale with $L=M=40, N=20$, $s_{L}=w_{M}=40$, and $P_{N}=5$. 
In each period $t$, we define the functions

$$
\begin{aligned}
\Theta_{t}\left(s_{l}, P_{n}\right)= & \sum_{i=1}^{I} \sum_{j=1}^{J} \sum_{k=1}^{K} p_{\nu, i} p_{\eta, j} p_{\epsilon, k} \beta\left[R_{f}+a_{t}\left(s_{l}, P_{n}\right)\left(\bar{R}_{e} \nu_{i}-R_{f}\right)\right]\left(G_{t+1} \eta_{j}\right)^{-\gamma} \\
& \times u_{b, t+1}\left(w_{t+1}\left(s_{l}, P_{n} ; \nu_{i}, \eta_{j}, \epsilon_{k}\right), G_{t+1} P_{n} \eta_{j}\right), \\
\Omega_{t}\left(s_{l}, P_{n}\right)= & \sum_{i=1}^{I} \sum_{j=1}^{J} \sum_{k=1}^{K} p_{\nu, i} p_{\eta, j} p_{\epsilon, k} \beta s_{l}\left(\bar{R}_{e} \nu_{i}-R_{f}\right)\left(G_{t+1} \eta_{j}\right)^{-\gamma} \\
& \times u_{b, t+1}\left(w_{t+1}\left(s_{l}, P_{n} ; \nu_{i}, \eta_{j}, \epsilon_{k}\right), G_{t+1} P_{n} \eta_{j}\right),
\end{aligned}
$$

where

$$
\begin{aligned}
u_{b t}\left(w_{t}, P_{t}\right) & =b_{t}\left(w_{t}, P_{t}\right)^{-\gamma}\left(1+\frac{\alpha(1-\lambda)}{1-\phi} P_{t}^{\lambda-\phi} \frac{l_{t}\left(w_{t}, P_{t}\right)^{1-\phi}}{b_{t}\left(w_{t}, P_{t}\right)^{1-\lambda}}\right)^{(\lambda-\gamma) /(1-\lambda)}, \\
l_{t}\left(w_{t}, P_{t}\right) & =\frac{\alpha^{1 / \phi} P_{t}^{\lambda / \phi-1} b_{t}\left(w_{t}, P_{t}\right)^{\lambda / \phi}}{Q_{t}^{1 / \phi}}, \\
w_{t+1}\left(s_{l}, P_{n} ; \nu_{i}, \eta_{j}, \epsilon_{k}\right) & =\frac{\left[R_{f}+a_{t}\left(s_{l}, P_{n}\right)\left(\bar{R}_{e} \nu_{i}-R_{f}\right)\right] s_{l}}{G_{t+1} \eta_{j}}+\epsilon_{k} .
\end{aligned}
$$

Starting with the solution in period $T$, we use the following algorithm to solve the lifecycle problem recursively for periods $t=T-1, \ldots, 1$.

1. For each point $\left(s_{l}, P_{n}\right)$ on the grid, find $a_{t}\left(s_{l}, P_{n}\right)$ such that $\Omega_{t}\left(s_{l}, P_{n}\right)=0$. If an interior solution does not exist,

$$
a_{t}\left(s_{l}, P_{n}\right)=\left\{\begin{array}{ll}
0 & \text { if } \Omega_{t}\left(s_{l}, P_{n}\right)<0 \\
1 & \text { if } \Omega_{t}\left(s_{l}, P_{n}\right)>0
\end{array}\right. \text {. }
$$

2. For each point $\left(s_{l}, P_{n}\right)$ on the grid, find $b_{t}\left(s_{l}, P_{n}\right)$ and $l_{t}\left(s_{l}, P_{n}\right)$ such that $u_{b t}\left(s_{l}, P_{n}\right)=$ $\Theta_{t}\left(s_{l}, P_{n}\right)$.

3. Define $w_{l}=s_{l}+b_{t}\left(s_{l}, P_{n}\right)+Q_{t} l_{t}\left(s_{l}, P_{n}\right), a_{t}\left(w_{l}, P_{n}\right)=a_{t}\left(s_{l}, P_{n}\right)$ (with a slight abuse of notation), and $b_{t}\left(w_{l}, P_{n}\right)=b_{t}\left(s_{l}, P_{n}\right)$. 
4. For each point $\left(w_{m}, P_{n}\right)$ on the grid, compute $a_{t}\left(w_{m}, P_{n}\right)$ by interpolating $a_{t}\left(w_{l}, P_{n}\right)$ as a function of $w_{l}$ and imposing the constraint $a_{t}\left(w_{m}, P_{n}\right) \in[0,1]$.

5. For each point $\left(w_{m}, P_{n}\right)$ on the grid, compute $b_{t}\left(w_{m}, P_{n}\right)$ by interpolating $b_{t}\left(w_{l}, P_{n}\right)$ as a function of $w_{l}$. Compute $l_{t}\left(w_{m}, P_{n}\right)=\alpha^{1 / \phi} Q_{t}^{-1 / \phi} P_{n}^{\lambda / \phi-1} b_{t}\left(w_{m}, P_{n}\right)^{\lambda / \phi}$. 


\section{References}

Aitt-Sahalia, Y., J. A. Parker, and M. Yogo, 2004, "Luxury Goods and the Equity Premium," Journal of Finance, 59(6), 2959-3004.

Aizcorbe, A. M., A. B. Kennickell, and K. B. Moore, 2003, "Recent Changes in U.S. Family Finances: Evidence from the 1998 and 2001 Survey of Consumer Finances," Federal Reserve Bulletin, 89(1), 1-32.

Ameriks, J., and S. P. Zeldes, 2004, "How Do Household Portfolio Shares Vary with Age?," Working paper, Columbia University.

Attanasio, O. P., and G. Weber, 1995, "Is Consumption Growth Consistent with Intertemporal Optimization? Evidence from the Consumer Expenditure Survey," Journal of Political Economy, 103(6), 1121-1157.

Balduzzi, P., and A. W. Lynch, 1999, "Transaction Costs and Predictability: Some Utility Cost Calculations," Journal of Financial Economics, 52(1), 47-78.

Barberis, N., 2000, "Investing for the Long Run when Returns Are Predictable," Journal of Finance, 55(1), 225-264.

Benzoni, L., P. Collin-Dufresne, and R. S. Goldstein, 2007, "Portfolio Choice over the LifeCycle when the Stock and Labor Markets Are Cointegrated," Journal of Finance, 62(5), 2123-2167.

Bertaut, C. C., and M. Haliassos, 1997, "Precautionary Portfolio Behavior from a Life-Cycle Perspective," Journal of Economic Dynamics and Control, 21(8-9), 1511-1542.

Bertaut, C. C., and M. Starr-McCluer, 2002, "Household Portfolios in the United States," in Household Portfolios, ed. by L. Guiso, M. Haliassos, and T. Jappelli. MIT Press, Cambridge, MA, chap. 5, pp. 181-217. 
Bils, M., and P. J. Klenow, 1998, "Using Consumer Theory to Test Competing Business Cycle Models," Journal of Political Economy, 106(2), 233-261.

Blume, M. E., and I. Friend, 1975, "The Asset Structure of Individual Portfolios and Some Implications for Utility Functions," Journal of Finance, 30(2), 585-603.

Bodie, Z., R. C. Merton, and W. F. Samuelson, 1992, "Labor Supply Flexibility and Portfolio Choice in a Life Cycle Model," Journal of Economic Dynamics and Control, 16(3-4), 427449.

Brav, A., G. M. Constantinides, and C. C. Geczy, 2002, "Asset Pricing with Heterogeneous Consumers and Limited Participation: Empirical Evidence," Journal of Political Economy, $110(4), 793-824$.

Brunnermeier, M. K., and S. Nagel, 2008, "Do Wealth Fluctuations Generate Time-Varying Risk Aversion? Micro-Evidence on Individuals' Asset Allocation," American Economic Review, 98(3), 713-736.

Calvet, L. E., J. Y. Campbell, and P. Sodini, 2007, "Down or Out: Assessing the Welfare Costs of Household Investment Mistakes," Journal of Political Economy, 115(5), 707-747.

Campbell, J. Y., 2006, "Household Finance," Journal of Finance, 61(4), 1553-1604.

Campbell, J. Y., J. F. Cocco, F. J. Gomes, and P. J. Maenhout, 2001, "Investing Retirement Wealth: A Life Cycle Model," in Risk Aspects of Investment-Based Social Security Reform, ed. by J. Y. Campbell, and M. Feldstein. University of Chicago Press, Chicago, chap. 11, pp. $439-473$.

Campbell, J. Y., and J. H. Cochrane, 1999, "By Force of Habit: A Consumption-Based Explanation of Aggregate Stock Market Behavior," Journal of Political Economy, 107(2), $205-251$. 
Campbell, J. Y., and L. M. Viceira, 1999, "Consumption and Portfolio Decisions When Expected Returns are Time Varying," Quarterly Journal of Economics, 114(2), 433-495.

Carroll, C. D., 1992, "The Buffer-Stock Theory of Saving: Some Macroeconomic Evidence," Brookings Papers on Economic Activity, 23(2), 61-156.

— , 1997, "Buffer-Stock Saving and the Life Cycle/Permanent Income Hypothesis," Quarterly Journal of Economics, 112(1), 1-55.

— 2000, "Why Do the Rich Save So Much?," in Does Atlas Shrug? The Economic Consequences of Taxing the Rich, ed. by J. B. Slemrod. Harvard University Press, Cambridge, MA.

— , 2002, "Portfolios of the Rich," in Household Portfolios, ed. by L. Guiso, M. Haliassos, and T. Jappelli. MIT Press, Cambridge, MA, chap. 10, pp. 389-429.

Carroll, C. D., and A. A. Samwick, 1997, "The Nature of Precautionary Wealth," Journal of Monetary Economics, 40(1), 41-71.

Chan, Y. L., and L. Kogan, 2002, "Catching up with the Joneses: Heterogeneous Preferences and the Dynamics of Asset Prices," Journal of Political Economy, 110(6), 1255-1285.

Cocco, J. F., 2005, "Portfolio Choice in the Presence of Housing," Review of Financial Studies, 18(2), 535-567.

Cocco, J. F., F. J. Gomes, and P. J. Maenhout, 2005, "Consumption and Portfolio Choice over the Life Cycle," Review of Financial Studies, 18(2), 491-533.

Davis, S. J., and P. Willen, 2002, "Income Shocks, Asset Returns, and Portfolio Choice," in Innovations in Retirement Financing, ed. by Z. Bodie, O. S. Mitchell, P. B. Hammond, and S. Zeldes. University of Pennsylvania Press, Philadelphia, PA, chap. 2, pp. 20-49.

Deaton, A., and J. Muellbauer, 1980, Economics and Consumer Behavior. Cambridge University Press, Cambridge. 
Friend, I., and M. E. Blume, 1975, "The Demand for Risky Assets," American Economic Review, 65(5), 900-922.

Gakidis, H. E., 1998, "Stocks for the Old? Earnings Uncertainty and Life-Cycle Portfolio Choice," Ph.D. dissertation, MIT.

Gârleanu, N., and S. Panageas, 2008, "Young, Old, Conservative and Bold: The Implications of Heterogeneity and Finite Lives for Asset Pricing," Working Paper, University of California, Berkeley.

Gomes, F., and A. Michaelides, 2003, "Portfolio Choice with Internal Habit Formation: A Life-Cycle Model with Uninsurable Labor Income Risk," Review of Economic Dynamics, 6(4), 729-766.

— , 2005, "Optimal Life-Cycle Asset Allocation: Understanding the Empirical Evidence," Journal of Finance, 60(2), 869-904.

Gourinchas, P.-O., and J. A. Parker, 2002, "Consumption over the Life Cycle," Econometrica, $70(1), 47-89$.

Guiso, L., M. Haliassos, and T. Jappelli, 2002, Household Portfolios. MIT Press, Cambridge, MA.

Haliassos, M., and C. C. Bertaut, 1995, "Why Do So Few Hold Stocks?," Economic Journal, 105(432), 1110-1129.

Hanoch, G., 1977, "Risk Aversion and Consumer Preferences," Econometrica, 45(2), 413426.

Heaton, J., and D. Lucas, 1997, "Market Frictions, Savings Behavior, and Portfolio Choice," Macroeconomic Dynamics, 1(1), 76-101.

Houthakker, H. S., 1960, "Additive Preferences," Econometrica, 28(2), 244-257. 
Hu, X., 2005, "Portfolio Choices for Homeowners," Journal of Urban Economics, 58(1), $114-136$.

Hubbard, R. G., J. Skinner, and S. P. Zeldes, 1995, "Precautionary Saving and Social Insurance," Journal of Political Economy, 103(2), 360-399.

Kim, T. S., and E. Omberg, 1996, "Dynamic Nonmyopic Portfolio Behavior," Review of Financial Studies, 9(1), 141-161.

Leser, C. E. V., 1963, "Forms of Engel Functions," Econometrica, 31(4), 694-703.

Lochstoer, L. A., 2009, "Expected Returns and the Business Cycle: Heterogeneous Goods and Time-Varying Risk Aversion," Review of Financial Studies, 22(12), 5251-5294.

Lynch, A. W., and S. Tan, 2010, "Labor Income Dynamics and Business-Cycle Frequencies: Implications for Portfolio Choice," Journal of Financial Economics, forthcoming.

Malloy, C. J., T. J. Moskowitz, and A. Vissing-Jørgensen, 2009, "Long-Run Stockholder Consumption Risk and Asset Returns," Journal of Finance, 64(6), 2427-2479.

Mankiw, N. G., and S. P. Zeldes, 1991, "The Consumption of Stockholders and Nonstockholders," Journal of Financial Economics, 29(1), 97-112.

Ogaki, M., 1992, "Engel's Law and Cointegration," Journal of Political Economy, 100(5), $1027-1046$.

Pakoš, M., 2004, "Asset Pricing with Durable Goods and Non-Homothetic Preferences," Working paper, University of Chicago.

Parker, J. A., 2001, "The Consumption Risk of the Stock Market," Brookings Papers on Economic Activity, 2, 279-333.

Polkovnichenko, V., 2007, "Life-Cycle Portfolio Choice with Additive Habit Formation Preferences and Uninsurable Labor Income Risk," Review of Financial Studies, 20(1), 83-124. 
Prais, S. J., and H. S. Houthakker, 1955, The Analysis of Family Budgets. Cambridge University Press, Cambridge.

Roussanov, N. L., 2010, "Diversification and its Discontents: Idiosyncratic and Entrepreneurial Risk in the Quest for Social Status," Journal of Finance, forthcoming.

Shim, K. H., 2009, "Household Portfolio Choice When Labor Income Shocks Are Persistent and the Overallocation Problem," PhD dissertation, Chapter 3, University of British Columbia.

Stiglitz, J. E., 1969, "Behavior Towards Risk with Many Commodities," Econometrica, 4(37), $660-667$.

Stone, R., 1954, The Measurement of Consumers' Expenditure and Behaviour in the United Kingdom, 1920-1938, vol. I. Cambridge University Press, Cambridge.

Storesletten, K., C. Telmer, and A. Yaron, 2007, "Asset Pricing with Idiosyncratic Risk and Overlapping Generations," Review of Economic Dynamics, 10(4), 519-548.

Viceira, L. M., 2001, "Optimal Portfolio Choice for Long-Horizon Investors with Nontradable Labor Income," Journal of Finance, 56(2), 433-470.

Vissing-Jørgensen, A., 2002, "Limited Asset Market Participation and the Elasticity of Intertemporal Substitution," Journal of Political Economy, 110(4), 825-853.

Wachter, J. A., 2002, "Portfolio and Consumption Decisions under Mean-Reverting Returns: An Exact Solution for Complete Markets," Journal of Financial and Quantitative Analysis, 37(1), 63-91.

Working, H., 1943, "Statistical Laws of Family Expenditure," Journal of the American Statistical Association, 38(221), 43-56.

Yao, R., and H. H. Zhang, 2005, "Optimal Consumption and Portfolio Choices with Risky Housing and Borrowing Constraints," Review of Financial Studies, 18(1), 197-239. 
Zeldes, S. P., 1989, "Optimal Consumption with Stochastic Income: Deviations from Certainty Equivalence," Quarterly Journal of Economics, 104(2), 275-298. 
Table 1: Relation between the expenditure shares for nondurable goods and total consumption

\begin{tabular}{|c|c|c|c|c|c|c|}
\hline Explanatory variable & $\begin{array}{r}\text { Food } \\
\text { at } \\
\text { home }\end{array}$ & $\begin{array}{r}\text { Food } \\
\text { away from } \\
\text { home }\end{array}$ & $\begin{array}{r}\text { Clothing } \\
\text { and } \\
\text { shoes }\end{array}$ & $\begin{array}{r}\text { Fuel oil } \\
\text { and } \\
\text { coal }\end{array}$ & Gasoline & $\begin{array}{r}\text { Other } \\
\text { nondurable } \\
\text { goods }\end{array}$ \\
\hline \multicolumn{7}{|l|}{ Age: } \\
\hline $26-35$ & $\begin{array}{r}-1.39 \\
(-4.81)\end{array}$ & $\begin{array}{r}0.14 \\
(0.65)\end{array}$ & $\begin{array}{r}0.05 \\
(0.29)\end{array}$ & $\begin{array}{r}-0.22 \\
(-2.13)\end{array}$ & $\begin{array}{r}-0.71 \\
(-5.74)\end{array}$ & $\begin{array}{r}-0.16 \\
(-1.44)\end{array}$ \\
\hline $36-45$ & $\begin{array}{r}-0.20 \\
(-0.85)\end{array}$ & $\begin{array}{r}0.29 \\
(1.70)\end{array}$ & $\begin{array}{r}0.08 \\
(0.62)\end{array}$ & $\begin{array}{r}-0.15 \\
(-1.81)\end{array}$ & $\begin{array}{r}-0.43 \\
(-4.18)\end{array}$ & $\begin{array}{r}0.11 \\
(1.21)\end{array}$ \\
\hline $56-65$ & $\begin{array}{r}0.80 \\
(3.02)\end{array}$ & $\begin{array}{r}-0.42 \\
(-2.29)\end{array}$ & $\begin{array}{r}-0.34 \\
(-2.37)\end{array}$ & $\begin{array}{r}0.18 \\
(1.90)\end{array}$ & $\begin{array}{r}-0.30 \\
(-2.62)\end{array}$ & $\begin{array}{r}0.22 \\
(2.12)\end{array}$ \\
\hline $66-75$ & $\begin{array}{r}1.33 \\
(4.21)\end{array}$ & $\begin{array}{r}-1.25 \\
(-6.02)\end{array}$ & $\begin{array}{r}-0.67 \\
(-4.02)\end{array}$ & $\begin{array}{r}0.27 \\
(2.35)\end{array}$ & $\begin{array}{r}-0.89 \\
(-6.92)\end{array}$ & $\begin{array}{r}-0.13 \\
(-1.09)\end{array}$ \\
\hline Log consumption & $\begin{array}{r}-8.05 \\
(-26.34)\end{array}$ & $\begin{array}{r}2.45 \\
(11.16)\end{array}$ & $\begin{array}{r}1.09 \\
(6.33)\end{array}$ & $\begin{array}{r}-0.20 \\
(-1.81)\end{array}$ & $\begin{array}{r}-2.45 \\
(-18.11)\end{array}$ & $\begin{array}{r}-0.61 \\
(-5.19)\end{array}$ \\
\hline \multicolumn{7}{|l|}{ Log consumption $\times$ Age: } \\
\hline $26-35$ & $\begin{array}{r}1.74 \\
(3.37)\end{array}$ & $\begin{array}{r}-0.49 \\
(-1.32)\end{array}$ & $\begin{array}{r}-0.26 \\
(-0.89)\end{array}$ & $\begin{array}{r}0.14 \\
(0.69)\end{array}$ & $\begin{array}{r}-0.34 \\
(-1.51)\end{array}$ & $\begin{array}{r}0.57 \\
(2.87)\end{array}$ \\
\hline $36-45$ & $\begin{array}{r}0.50 \\
(1.16)\end{array}$ & $\begin{array}{r}-0.58 \\
(-1.88)\end{array}$ & $\begin{array}{r}-0.18 \\
(-0.76)\end{array}$ & $\begin{array}{r}0.26 \\
(1.63)\end{array}$ & $\begin{array}{r}-0.03 \\
(-0.16)\end{array}$ & $\begin{array}{r}-0.15 \\
(-0.92)\end{array}$ \\
\hline $56-65$ & $\begin{array}{r}0.28 \\
(0.65)\end{array}$ & $\begin{array}{r}-0.15 \\
(-0.50)\end{array}$ & $\begin{array}{r}-0.49 \\
(-2.04)\end{array}$ & $\begin{array}{r}0.08 \\
(0.53)\end{array}$ & $\begin{array}{r}0.44 \\
(2.35)\end{array}$ & $\begin{array}{r}-0.13 \\
(-0.81)\end{array}$ \\
\hline $66-75$ & $\begin{array}{r}0.17 \\
(0.39)\end{array}$ & $\begin{array}{r}-0.01 \\
(-0.04)\end{array}$ & $\begin{array}{r}-0.25 \\
(-1.00)\end{array}$ & $\begin{array}{r}0.09 \\
(0.58)\end{array}$ & $\begin{array}{r}0.88 \\
(4.58)\end{array}$ & $\begin{array}{r}0.28 \\
(1.67)\end{array}$ \\
\hline Not married & $\begin{array}{r}-1.65 \\
(-6.42)\end{array}$ & $\begin{array}{r}-0.32 \\
(-1.73)\end{array}$ & $\begin{array}{r}-0.13 \\
(-0.86)\end{array}$ & $\begin{array}{r}-0.13 \\
(-1.42)\end{array}$ & $\begin{array}{r}-0.79 \\
(-7.14)\end{array}$ & $\begin{array}{r}-0.09 \\
(-0.94)\end{array}$ \\
\hline \multicolumn{7}{|l|}{ Household size: } \\
\hline 1 & $\begin{array}{r}-7.68 \\
(-24.49)\end{array}$ & $\begin{array}{r}3.36 \\
(11.35)\end{array}$ & $\begin{array}{r}-0.88 \\
(-4.54)\end{array}$ & $\begin{array}{r}-0.21 \\
(-1.63)\end{array}$ & $\begin{array}{r}-1.72 \\
(-12.10)\end{array}$ & $\begin{array}{r}-0.33 \\
(-2.44)\end{array}$ \\
\hline 2 & $\begin{array}{r}-4.33 \\
(-18.29)\end{array}$ & $\begin{array}{r}1.90 \\
(10.55)\end{array}$ & $\begin{array}{r}-0.58 \\
(-4.33)\end{array}$ & $\begin{array}{r}-0.09 \\
(-1.07)\end{array}$ & $\begin{array}{r}-0.59 \\
(-5.56)\end{array}$ & $\begin{array}{r}0.16 \\
(1.73)\end{array}$ \\
\hline 3 & $\begin{array}{r}-2.05 \\
(-8.08)\end{array}$ & $\begin{array}{r}0.59 \\
(3.10)\end{array}$ & $\begin{array}{r}-0.18 \\
(-1.28)\end{array}$ & $\begin{array}{r}0.04 \\
(0.39)\end{array}$ & $\begin{array}{r}-0.04 \\
(-0.36)\end{array}$ & $\begin{array}{r}0.17 \\
(1.64)\end{array}$ \\
\hline 5 & $\begin{array}{r}1.38 \\
(3.82)\end{array}$ & $\begin{array}{r}-0.18 \\
(-0.70)\end{array}$ & $\begin{array}{r}0.04 \\
(0.21)\end{array}$ & $\begin{array}{r}-0.16 \\
(-1.33)\end{array}$ & $\begin{array}{r}0.07 \\
(0.45)\end{array}$ & $\begin{array}{r}0.10 \\
(0.72)\end{array}$ \\
\hline 6 or more & $\begin{array}{r}2.76 \\
(5.29)\end{array}$ & $\begin{array}{r}-0.34 \\
(-0.96)\end{array}$ & $\begin{array}{r}-0.26 \\
(-0.97)\end{array}$ & $\begin{array}{r}-0.36 \\
(-2.19)\end{array}$ & $\begin{array}{r}0.90 \\
(3.77)\end{array}$ & $\begin{array}{r}0.15 \\
(0.78)\end{array}$ \\
\hline Observations & 9,739 & 9,739 & 9,739 & 9,739 & 9,739 & 9,739 \\
\hline
\end{tabular}

We estimate a censored regression model for the expenditure share for each category of nondurable goods. The latent variable depends on age group, log total (nondurable and service) consumption, $\log$ total consumption interacted with age group, marital status, household size, and interview-year dummies (not reported). The omitted category is households with four members, whose head is aged 46-55 and married. The sample consists of stockholders in the 1982-2003 CEX. The table reports the marginal effects at the mean of the regressors with corresponding $t$-statistics in parentheses. 
Table 2: Relation between the expenditure shares for services and total consumption

\begin{tabular}{|c|c|c|c|c|c|c|}
\hline Explanatory variable & Housing & $\begin{array}{r}\text { Household } \\
\text { operation }\end{array}$ & $\begin{array}{c}\text { Trans- } \\
\text { portation }\end{array}$ & $\begin{array}{r}\text { Personal } \\
\text { care }\end{array}$ & $\begin{array}{l}\text { Personal } \\
\text { business }\end{array}$ & Recreation \\
\hline \multicolumn{7}{|l|}{ Age: } \\
\hline \multirow[t]{2}{*}{$26-35$} & 2.76 & 0.96 & -0.74 & -0.15 & -0.54 & -0.19 \\
\hline & $(8.23)$ & $(3.18)$ & $(-3.18)$ & $(-2.88)$ & $(-3.24)$ & $(-1.39)$ \\
\hline \multirow[t]{2}{*}{$36-45$} & 0.38 & 0.70 & -0.92 & -0.10 & -0.19 & 0.53 \\
\hline & $(1.54)$ & $(2.89)$ & $(-4.91)$ & $(-2.28)$ & $(-1.33)$ & $(4.57)$ \\
\hline \multirow[t]{2}{*}{$56-65$} & 0.58 & 0.57 & -1.13 & -0.07 & 0.32 & -0.39 \\
\hline & $(2.12)$ & $(2.12)$ & $(-5.54)$ & $(-1.43)$ & $(2.00)$ & $(-3.26)$ \\
\hline \multirow[t]{2}{*}{$66-75$} & 1.41 & 1.04 & -0.09 & -0.09 & -0.26 & -0.28 \\
\hline & $(4.20)$ & $(3.22)$ & $(-0.35)$ & $(-1.66)$ & $(-1.40)$ & $(-1.97)$ \\
\hline \multirow[t]{2}{*}{ Log consumption } & 4.55 & -5.23 & 2.73 & 0.15 & 1.21 & 1.30 \\
\hline & $(14.55)$ & $(-16.87)$ & $(10.86)$ & $(2.60)$ & $(6.59)$ & $(8.98)$ \\
\hline \multicolumn{7}{|c|}{ Log consumption $\times$ Age: } \\
\hline \multirow[t]{2}{*}{$26-35$} & -0.49 & 1.92 & -0.41 & -0.18 & -0.43 & -0.87 \\
\hline & $(-0.92)$ & $(3.67)$ & $(-0.96)$ & $(-1.89)$ & $(-1.40)$ & $(-3.57)$ \\
\hline \multirow[t]{2}{*}{$36-45$} & -0.27 & 1.75 & -0.58 & -0.04 & -0.16 & 0.26 \\
\hline & $(-0.61)$ & $(4.00)$ & $(-1.62)$ & $(-0.44)$ & $(-0.61)$ & $(1.25)$ \\
\hline \multirow[t]{2}{*}{$56-65$} & 0.51 & -0.24 & -0.84 & -0.27 & 1.12 & -0.22 \\
\hline & $(1.17)$ & $(-0.56)$ & $(-2.38)$ & $(-3.35)$ & $(4.32)$ & $(-1.08)$ \\
\hline \multirow[t]{2}{*}{$66-75$} & -0.63 & -1.12 & 0.58 & -0.30 & 0.87 & 0.04 \\
\hline & $(-1.42)$ & $(-2.53)$ & $(1.60)$ & $(-3.69)$ & $(3.27)$ & $(0.20)$ \\
\hline \multirow[t]{2}{*}{ Not married } & 2.33 & -0.11 & 0.49 & 0.04 & -0.35 & -0.09 \\
\hline & $(8.16)$ & $(-0.43)$ & $(2.26)$ & $(0.74)$ & $(-2.25)$ & $(-0.74)$ \\
\hline \multicolumn{7}{|l|}{ Household size: } \\
\hline \multirow[t]{2}{*}{1} & 7.54 & -4.38 & 1.19 & -0.07 & 0.27 & 0.22 \\
\hline & $(15.71)$ & $(-12.88)$ & $(3.78)$ & $(-1.03)$ & $(1.22)$ & $(1.24)$ \\
\hline \multirow[t]{2}{*}{2} & 2.87 & -3.20 & 1.34 & 0.11 & 0.17 & 0.13 \\
\hline & $(10.87)$ & $(-13.27)$ & $(6.55)$ & $(2.50)$ & $(1.14)$ & (1.17) \\
\hline \multirow[t]{2}{*}{3} & 1.12 & -1.24 & 0.54 & 0.07 & 0.21 & -0.13 \\
\hline & $(3.95)$ & $(-4.77)$ & $(2.48)$ & (1.44) & $(1.35)$ & $(-1.09)$ \\
\hline \multirow[t]{2}{*}{5} & 0.26 & -1.06 & -0.43 & -0.11 & 0.02 & -0.05 \\
\hline & $(0.71)$ & $(-3.03)$ & $(-1.51)$ & $(-1.76)$ & $(0.11)$ & $(-0.29)$ \\
\hline \multirow[t]{2}{*}{6 or more } & -0.20 & -0.85 & -0.63 & -0.33 & 0.11 & -0.57 \\
\hline & $(-0.39)$ & $(-1.70)$ & $(-1.60)$ & $(-3.91)$ & $(0.35)$ & $(-2.57)$ \\
\hline Observations & 9,739 & 9,739 & 9,739 & 9,739 & 9,739 & 9,739 \\
\hline
\end{tabular}

We estimate a censored regression model for the expenditure share for each category of services. The latent variable depends on age group, log total (nondurable and service) consumption, log total consumption interacted with age group, marital status, household size, and interview-year dummies (not reported). The omitted category is households with four members, whose head is aged 46-55 and married. The sample consists of stockholders in the 1982-2003 CEX. The table reports the marginal effects at the mean of the regressors with corresponding $t$-statistics in parentheses 18 
Table 3: Expenditure shares for basic and luxury goods

\begin{tabular}{lrrrrr}
\hline Consumption category & \multicolumn{5}{c}{ Age } \\
\cline { 2 - 6 } & $26-35$ & $36-45$ & $46-55$ & $56-65$ & $66-75$ \\
\hline Panel A: Basic goods & 15.8 & 17.9 & 16.6 & 17.0 & 18.6 \\
Food at home & 5.7 & 5.7 & 5.9 & 5.6 & 4.7 \\
Gasoline & 3.0 & 3.4 & 3.1 & 3.6 & 3.1 \\
Other nondurable goods & 15.9 & 16.0 & 15.2 & 15.6 & 17.7 \\
Household operation & & & & & \\
Panel B: Luxury goods & 8.4 & 8.6 & 8.3 & 7.9 & 6.5 \\
Food away from home & 5.8 & 6.4 & 5.9 & 4.8 & 4.0 \\
Cothing and shoes & 7.7 & 5.7 & 6.4 & 6.6 & 8.2 \\
Housing & 8.7 & 8.3 & 9.7 & 8.8 & 8.2 \\
Transportation & 3.3 & 3.8 & 3.8 & 3.2 & 1.7 \\
Personal business & 4.7 & 5.4 & 5.0 & 4.3 & 3.9 \\
Recreation & 0.0 & 0.0 & 0.0 & 0.0 & 0.0 \\
\hline Panel C: Neither basic nor luxury good & & & & \\
Fuel oil and coal & 1.9 & 1.9 & 2.0 & 2.0 & 2.0 \\
Personal care & & & & &
\end{tabular}

We sort the sample of stockholders in the 1982-2003 CEX into age groups (columns). Panel A reports the median of expenditure shares, as a percentage of total consumption, for basic goods. Basic goods are those nondurable goods and services for which the expenditure share falls in total consumption for all age groups. Panel B reports the median of expenditure shares for luxury goods. Luxury goods are those nondurable goods and services for which the expenditure share rises in total consumption for all age groups. Panel $\mathrm{C}$ reports the median of expenditure shares for goods that are neither basic nor luxury. 
Table 4: Relation between the portfolio share and net worth for stockholders

\begin{tabular}{lrrr}
\hline Explanatory variable & $\begin{array}{r}\text { Main } \\
\text { specification }\end{array}$ & $\begin{array}{r}\text { Cohort } \\
\text { effects }\end{array}$ & $\begin{array}{r}\text { Alternative } \\
\text { definition of } \\
\text { stockholding }\end{array}$ \\
\hline Age: & & & \\
$26-35$ & -0.40 & -4.66 & -2.08 \\
& $(-1.47)$ & $(-13.23)$ & $(-6.72)$ \\
$36-45$ & 0.40 & -1.99 & -0.38 \\
& $(1.94)$ & $(-8.15)$ & $(-1.62)$ \\
$56-65$ & -2.73 & -1.02 & -1.46 \\
& $(-12.85)$ & $(-3.75)$ & $(-5.81)$ \\
$66-75$ & -6.13 & -2.73 & -4.67 \\
& $(-26.84)$ & $(-6.80)$ & $(-16.09)$ \\
Log net worth & 3.56 & 3.58 & 1.58 \\
& $(35.61)$ & $(35.86)$ & $(13.74)$ \\
Log net worth $\times$ Age: & & & \\
$26-35$ & -3.04 & -3.05 & -1.23 \\
& $(-20.63)$ & $(-20.71)$ & $(-7.29)$ \\
$36-45$ & -1.72 & -1.74 & -1.05 \\
& $(-12.86)$ & $(-13.03)$ & $(-6.87)$ \\
$56-65$ & 0.32 & 0.25 & -0.12 \\
& $(2.05)$ & $(1.59)$ & $(-0.66)$ \\
$66-75$ & 0.76 & 0.73 & 0.31 \\
& $(4.03)$ & $(3.86)$ & $(1.34)$ \\
Not married & -0.17 & -0.16 & 0.10 \\
Household size: & $(-0.61)$ & $(-0.59)$ & $(0.32)$ \\
1 & & & \\
& 4.39 & 4.51 & 1.35 \\
2 & $(12.00)$ & $(12.29)$ & $(3.31)$ \\
& 1.66 & 1.83 & 0.11 \\
3 & $(7.74)$ & $(8.49)$ & $(0.46)$ \\
5 & 0.39 & 0.43 & -0.75 \\
& $(1.70)$ & $(1.85)$ & $(-2.87)$ \\
6 or more & 1.03 & 1.02 & 0.81 \\
Observations & $(3.44)$ & $(3.43)$ & $(2.40)$ \\
& 2.46 & 2.30 & -1.79 \\
& $(5.38)$ & $(5.03)$ & $(-3.36)$ \\
& 71,271 & 71,271 & 62,157 \\
\hline & & & \\
& & & \\
& & &
\end{tabular}

We estimate a censored regression model for the portfolio share. The latent variable depends on age group, log net worth, log net worth interacted with age group, marital status, household size, and interview-year dummies (not reported). The omitted category is households with four members, whose head is aged 46-55 and married. In a second specification, we include cohort dummies, instead of interview-year dummies. In a third specification, we define the portfolio share as the share of financial wealth in stocks, instead of the share of net worth in risky assets. The sample consisto of stockholders in the 1989-2004 Survey of Consumer Finances. The table reports the marginal effects at the mean of the regressors with corresponding $t$-statistics in parentheses. 
Table 5: Relation between the portfolio share and net worth for stockholders by education

\begin{tabular}{|c|c|c|c|c|}
\hline Explanatory variable & $\begin{array}{r}\text { No } \\
\text { high } \\
\text { school }\end{array}$ & $\begin{array}{r}\text { High } \\
\text { school } \\
\text { graduates }\end{array}$ & $\begin{array}{r}\text { Some } \\
\text { college }\end{array}$ & $\begin{array}{r}\text { College } \\
\text { graduates }\end{array}$ \\
\hline \multicolumn{5}{|l|}{ Age: } \\
\hline $26-35$ & $\begin{array}{r}0.51 \\
(0.40)\end{array}$ & $\begin{array}{r}-2.83 \\
(-5.00)\end{array}$ & $\begin{array}{r}-1.18 \\
(-1.73)\end{array}$ & $\begin{array}{r}1.00 \\
(2.83)\end{array}$ \\
\hline $36-45$ & $\begin{array}{r}2.80 \\
(2.57)\end{array}$ & $\begin{array}{r}-0.64 \\
(-1.40)\end{array}$ & $\begin{array}{r}0.18 \\
(0.34)\end{array}$ & $\begin{array}{r}1.20 \\
(4.51)\end{array}$ \\
\hline $56-65$ & $\begin{array}{r}-5.65 \\
(-6.07)\end{array}$ & $\begin{array}{r}-3.27 \\
(-7.15)\end{array}$ & $\begin{array}{r}-3.24 \\
(-5.76)\end{array}$ & $\begin{array}{r}-1.32 \\
(-4.55)\end{array}$ \\
\hline $66-75$ & $\begin{array}{r}-4.91 \\
(-4.88)\end{array}$ & $\begin{array}{r}-7.31 \\
(-14.41)\end{array}$ & $\begin{array}{r}-6.59 \\
(-11.16)\end{array}$ & $\begin{array}{r}-5.78 \\
(-17.43)\end{array}$ \\
\hline Log net worth & $\begin{array}{r}1.80 \\
(3.38)\end{array}$ & $\begin{array}{r}2.30 \\
(9.51)\end{array}$ & $\begin{array}{r}3.85 \\
(14.42)\end{array}$ & $\begin{array}{r}4.59 \\
(34.22)\end{array}$ \\
\hline \multicolumn{5}{|l|}{ Log net worth $\times$ Age: } \\
\hline $26-35$ & $\begin{array}{r}-1.29 \\
(-1.56)\end{array}$ & $\begin{array}{r}-2.33 \\
(-6.67)\end{array}$ & $\begin{array}{r}-4.58 \\
(-11.97)\end{array}$ & $\begin{array}{r}-3.75 \\
(-19.31)\end{array}$ \\
\hline $36-45$ & $\begin{array}{r}-2.32 \\
(-3.25)\end{array}$ & $\begin{array}{r}-1.39 \\
(-4.39)\end{array}$ & $\begin{array}{r}-2.98 \\
(-8.55)\end{array}$ & $\begin{array}{r}-1.61 \\
(-8.93)\end{array}$ \\
\hline $56-65$ & $\begin{array}{r}-0.03 \\
(-0.04)\end{array}$ & $\begin{array}{r}0.86 \\
(2.22)\end{array}$ & $\begin{array}{r}-0.46 \\
(-1.03)\end{array}$ & $\begin{array}{r}-0.49 \\
(-2.32)\end{array}$ \\
\hline $66-75$ & $\begin{array}{r}-0.26 \\
(-0.37)\end{array}$ & $\begin{array}{r}1.99 \\
(3.94)\end{array}$ & $\begin{array}{r}0.33 \\
(0.67)\end{array}$ & $\begin{array}{r}0.88 \\
(3.27)\end{array}$ \\
\hline Not married & $\begin{array}{r}2.45 \\
(1.69)\end{array}$ & $\begin{array}{r}-0.13 \\
(-0.23)\end{array}$ & $\begin{array}{r}-0.92 \\
(-1.54)\end{array}$ & $\begin{array}{r}0.32 \\
(0.75)\end{array}$ \\
\hline \multicolumn{5}{|l|}{ Household size: } \\
\hline 1 & $\begin{array}{r}1.41 \\
(0.77)\end{array}$ & $\begin{array}{r}5.00 \\
(6.17)\end{array}$ & $\begin{array}{r}2.94 \\
(3.60)\end{array}$ & $\begin{array}{r}4.27 \\
(8.21)\end{array}$ \\
\hline 2 & $\begin{array}{r}4.69 \\
(4.55)\end{array}$ & $\begin{array}{r}1.48 \\
(3.09)\end{array}$ & $\begin{array}{r}-0.60 \\
(-1.12)\end{array}$ & $\begin{array}{r}2.04 \\
(7.26)\end{array}$ \\
\hline 3 & $\begin{array}{r}3.26 \\
(2.76)\end{array}$ & $\begin{array}{r}0.86 \\
(1.76)\end{array}$ & $\begin{array}{r}-2.08 \\
(-3.67)\end{array}$ & $\begin{array}{r}0.69 \\
(2.25)\end{array}$ \\
\hline 5 & $\begin{array}{r}6.99 \\
(4.17)\end{array}$ & $\begin{array}{r}4.51 \\
(6.48)\end{array}$ & $\begin{array}{r}-4.47 \\
(-6.49)\end{array}$ & $\begin{array}{r}1.01 \\
(2.62)\end{array}$ \\
\hline 6 or more & $\begin{array}{r}11.09 \\
(5.52)\end{array}$ & $\begin{array}{r}0.48 \\
(0.49)\end{array}$ & $\begin{array}{r}3.77 \\
(2.88)\end{array}$ & $\begin{array}{r}2.11 \\
(3.58)\end{array}$ \\
\hline Observations & 3,493 & 13,990 & 11,093 & 42,695 \\
\hline
\end{tabular}

We estimate a censored regression model for the portfolio share, separately by education group. The latent variable depends on age group, log net worth, log net worth interacted with age group, marital status, household size, and interview-year dummies (not reported). The omitted category is households with four members, whose head is aged 46-55 and married. The sample consists of stockholders in the 1989-2004 Survey of Consumer Finances. The table reports the marginal effects at the mean of the regressors with corresponding $t$-statistics in parentheses. 
Table 6: Parameters in the benchmark calibration

\begin{tabular}{|c|c|c|c|}
\hline Parameter & Symbol & Nonhomothetic & Homothetic \\
\hline \multicolumn{4}{|l|}{ Preferences: } \\
\hline Subjective discount factor & $\beta$ & 0.96 & 0.96 \\
\hline Utility weight on the luxury good & $\alpha$ & 2.9 & \\
\hline Inverse of the elasticity of substitution as basic share approaches 0 & $\lambda$ & 2.0 & \\
\hline Inverse of the elasticity of substitution as basic share approaches 1 & $\phi$ & 1.1 & \\
\hline Relative risk aversion as basic share approaches 1 & $\gamma$ & 45 & 7 \\
\hline Strength of the bequest motive & $b$ & $2 \times 10^{6}$ & $1 \times 10^{2}$ \\
\hline \multicolumn{4}{|l|}{ Labor income: } \\
\hline Standard deviation of permanent shocks to income & $\sigma_{\eta}$ & $13.85 \%$ & $13.85 \%$ \\
\hline Standard devation of transitory shocks to income & $\sigma_{\epsilon}$ & $19.16 \%$ & $19.16 \%$ \\
\hline Correlation between permanent shock to income and stock returns & $\rho$ & 0.15 & 0.15 \\
\hline \multicolumn{4}{|l|}{ Asset returns: } \\
\hline Riskfree rate & $R_{f}-1$ & $2 \%$ & $2 \%$ \\
\hline Equity premium & $\bar{R}_{e}-R_{f}$ & $4 \%$ & $4 \%$ \\
\hline Standard deviation of stock returns & $\sigma_{\nu}$ & $18 \%$ & $18 \%$ \\
\hline
\end{tabular}

The table reports parameters used in the benchmark calibration of the life-cycle consumption and portfolio-choice model with stochastic labor income. In the nonhomothetic life-cycle model, the household has nonhomothetic utility over basic and luxury goods. The the homothetic life-cycle model, the household has power utility over a composite consumption good. In both models, we calibrate the level of risk aversion to match the portfolio share for the median household aged 46-55. We calibrate the strength of the bequest motive to match the wealth-income ratio for the median household aged 66-75. We solve and simulate both models at an annual frequency. 
Table 7: Basic expenditure share in the nonhomothetic life-cycle model

\begin{tabular}{|c|c|c|c|c|c|}
\hline \multirow[t]{2}{*}{ Percentile of consumption } & \multicolumn{5}{|c|}{ Age } \\
\hline & $26-35$ & $36-45$ & $46-55$ & $56-65$ & $66-75$ \\
\hline \multicolumn{6}{|c|}{ Panel A: Consumer Expenditure Survey (Stockholders only) } \\
\hline \multirow[t]{2}{*}{$0-25$} & 58 & 59 & 57 & 60 & 64 \\
\hline & $(0.9)$ & $(0.6)$ & $(0.7)$ & $(0.7)$ & $(0.9)$ \\
\hline \multirow{2}{*}{$25-50$} & 50 & 51 & 49 & 52 & 55 \\
\hline & $(0.9)$ & $(0.6)$ & $(0.6)$ & $(0.7)$ & $(0.8)$ \\
\hline \multirow[t]{2}{*}{$50-75$} & 41 & 46 & 44 & 46 & 46 \\
\hline & $(0.9)$ & $(0.6)$ & $(0.6)$ & $(0.7)$ & $(0.9)$ \\
\hline \multirow[t]{2}{*}{$75-100$} & 33 & 38 & 35 & 34 & 36 \\
\hline & $(1.0)$ & $(0.7)$ & $(0.6)$ & $(0.8)$ & $(0.9)$ \\
\hline \multirow[t]{2}{*}{ Top 5} & 26 & 30 & 27 & 28 & 29 \\
\hline & $(2.3)$ & (1.6) & $(1.4)$ & $(2.0)$ & (2.1) \\
\hline \multirow[t]{2}{*}{ All households } & 47 & 49 & 47 & 49 & 51 \\
\hline & $(0.5)$ & $(0.4)$ & $(0.4)$ & $(0.5)$ & $(0.5)$ \\
\hline \multicolumn{6}{|c|}{ Panel B: Nonhomothetic life-cycle model } \\
\hline $0-25$ & 61 & 58 & 60 & 62 & 63 \\
\hline $25-50$ & 51 & 49 & 50 & 53 & 54 \\
\hline $50-75$ & 44 & 43 & 43 & 45 & 47 \\
\hline $75-100$ & 36 & 35 & 35 & 36 & 38 \\
\hline Top 5 & 32 & 30 & 30 & 31 & 33 \\
\hline All households & 47 & 46 & 47 & 49 & 51 \\
\hline
\end{tabular}

We sort the sample of stockholders in the 1982-2003 CEX into age groups (columns), then into quartiles of total consumption within each age group and interview year (rows). Panel A reports the median of the basic expenditure share (i.e., basic consumption as a percentage of total consumption) with asymptotic standard errors in parentheses. Panel B reports the median of the basic expenditure share for households simulated in the nonhomothetic life-cycle model. 
Table 8: Portfolio share in the life-cycle model

\begin{tabular}{|c|c|c|c|c|c|}
\hline \multirow[t]{2}{*}{ Percentile of net worth } & \multicolumn{5}{|c|}{ Age } \\
\hline & $26-35$ & $36-45$ & $46-55$ & $56-65$ & $66-75$ \\
\hline \multicolumn{6}{|c|}{ Panel A: Survey of Consumer Finances (Stockholders only) } \\
\hline \multirow{2}{*}{$0-25$} & 25 & 23 & 19 & 18 & 15 \\
\hline & (7.9) & $(12.5)$ & $(3.9)$ & (1.1) & $(1.0)$ \\
\hline \multirow{2}{*}{$25-50$} & 21 & 19 & 22 & 20 & 16 \\
\hline & $(0.8)$ & $(0.6)$ & $(0.6)$ & $(0.6)$ & $(0.8)$ \\
\hline \multirow{2}{*}{$50-75$} & 23 & 25 & 30 & 30 & 24 \\
\hline & $(1.0)$ & $(0.6)$ & $(0.5)$ & $(0.6)$ & $(0.7)$ \\
\hline \multirow[t]{2}{*}{$75-100$} & 40 & 44 & 51 & 47 & 44 \\
\hline & $(0.7)$ & $(0.4)$ & $(0.3)$ & $(0.3)$ & $(0.4)$ \\
\hline \multirow[t]{2}{*}{ Top 5} & 61 & 67 & 68 & 65 & 65 \\
\hline & $(1.2)$ & $(0.5)$ & $(0.4)$ & $(0.4)$ & $(0.5)$ \\
\hline \multirow[t]{2}{*}{ All households } & 26 & 28 & 30 & 29 & 22 \\
\hline & (1.9) & $(2.6)$ & $(0.8)$ & $(0.3)$ & $(0.3)$ \\
\hline \multicolumn{6}{|c|}{ Panel B: Nonhomothetic life-cycle model } \\
\hline $0-25$ & 100 & 29 & 19 & 17 & 15 \\
\hline $25-50$ & 67 & 32 & 25 & 23 & 19 \\
\hline $50-75$ & 49 & 35 & 31 & 28 & 21 \\
\hline $75-100$ & 43 & 42 & 39 & 34 & 24 \\
\hline Top 5 & 42 & 44 & 43 & 36 & 26 \\
\hline All households & 63 & 35 & 28 & 25 & 20 \\
\hline \multicolumn{6}{|c|}{$\begin{array}{l}\text { Panel C: Homothetic life-cycle model } \\
\end{array}$} \\
\hline $0-25$ & 100 & 47 & 32 & 26 & 22 \\
\hline $25-50$ & 100 & 44 & 32 & 27 & 23 \\
\hline $50-75$ & 77 & 42 & 32 & 27 & 24 \\
\hline $75-100$ & 60 & 40 & 32 & 28 & 25 \\
\hline Top 5 & 55 & 40 & 32 & 28 & 25 \\
\hline All households & 90 & 43 & 32 & 27 & 23 \\
\hline
\end{tabular}

We sort the sample of stockholders in the 1989-2004 Survey of Consumer Finances into age groups (columns), then into quartiles of net worth within each age group and interview year (rows). Panel A reports the median of the portfolio share (i.e., risky assets as a percentage of net worth) with asymptotic standard errors in parentheses. Panel B (Panel C) reports the median of the portfolio share for households simulated in the nonhomothetic (homothetic) life-cycle model. 
Table 9: Portfolio share in the life-cycle model with unemployment risk

\begin{tabular}{|c|c|c|c|c|c|}
\hline \multirow[t]{2}{*}{ Percentile of net worth } & \multicolumn{5}{|c|}{ Age } \\
\hline & $26-35$ & $36-45$ & $46-55$ & $56-65$ & $66-75$ \\
\hline \multicolumn{6}{|c|}{ Panel A: Survey of Consumer Finances (Stockholders only) } \\
\hline \multirow[t]{2}{*}{$0-25$} & 25 & 23 & 19 & 18 & 15 \\
\hline & (7.9) & $(12.5)$ & $(3.9)$ & (1.1) & $(1.0)$ \\
\hline \multirow{2}{*}{$25-50$} & 21 & 19 & 22 & 20 & 16 \\
\hline & $(0.8)$ & $(0.6)$ & $(0.6)$ & $(0.6)$ & $(0.8)$ \\
\hline \multirow{2}{*}{$50-75$} & 23 & 25 & 30 & 30 & 24 \\
\hline & $(1.0)$ & $(0.6)$ & $(0.5)$ & $(0.6)$ & $(0.7)$ \\
\hline \multirow[t]{2}{*}{$75-100$} & 40 & 44 & 51 & 47 & 44 \\
\hline & $(0.7)$ & $(0.4)$ & $(0.3)$ & $(0.3)$ & $(0.4)$ \\
\hline \multirow[t]{2}{*}{ Top 5} & 61 & 67 & 68 & 65 & 65 \\
\hline & $(1.2)$ & $(0.5)$ & $(0.4)$ & $(0.4)$ & $(0.5)$ \\
\hline \multirow[t]{2}{*}{ All households } & 26 & 28 & 30 & 29 & 22 \\
\hline & (1.9) & $(2.6)$ & $(0.8)$ & $(0.3)$ & $(0.3)$ \\
\hline \multicolumn{6}{|c|}{ Panel B: Nonhomothetic life-cycle model } \\
\hline $0-25$ & 7 & 22 & 18 & 17 & 15 \\
\hline $25-50$ & 19 & 29 & 25 & 23 & 19 \\
\hline $50-75$ & 24 & 33 & 31 & 28 & 21 \\
\hline $75-100$ & 27 & 38 & 40 & 34 & 24 \\
\hline Top 5 & 27 & 40 & 43 & 36 & 26 \\
\hline All households & 20 & 30 & 28 & 25 & 20 \\
\hline \multicolumn{6}{|c|}{$\begin{array}{l}\text { Panel C: Homothetic life-cycle model } \\
\end{array}$} \\
\hline $0-25$ & 50 & 46 & 32 & 26 & 22 \\
\hline $25-50$ & 91 & 43 & 32 & 26 & 23 \\
\hline $50-75$ & 74 & 42 & 32 & 27 & 23 \\
\hline $75-100$ & 59 & 40 & 32 & 28 & 24 \\
\hline Top 5 & 54 & 39 & 33 & 28 & 25 \\
\hline All households & 71 & 42 & 32 & 27 & 23 \\
\hline
\end{tabular}

We sort the sample of stockholders in the 1989-2004 Survey of Consumer Finances into age groups (columns), then into quartiles of net worth within each age group and interview year (rows). Panel A reports the median of the portfolio share (i.e., risky assets as a percentage of net worth) with asymptotic standard errors in parentheses. Panel B (Panel C) reports the median of the portfolio share for households simulated in the nonhomothetic (homothetic) life-cycle model. The probability of unemployment in the model is $0.5 \%$. 

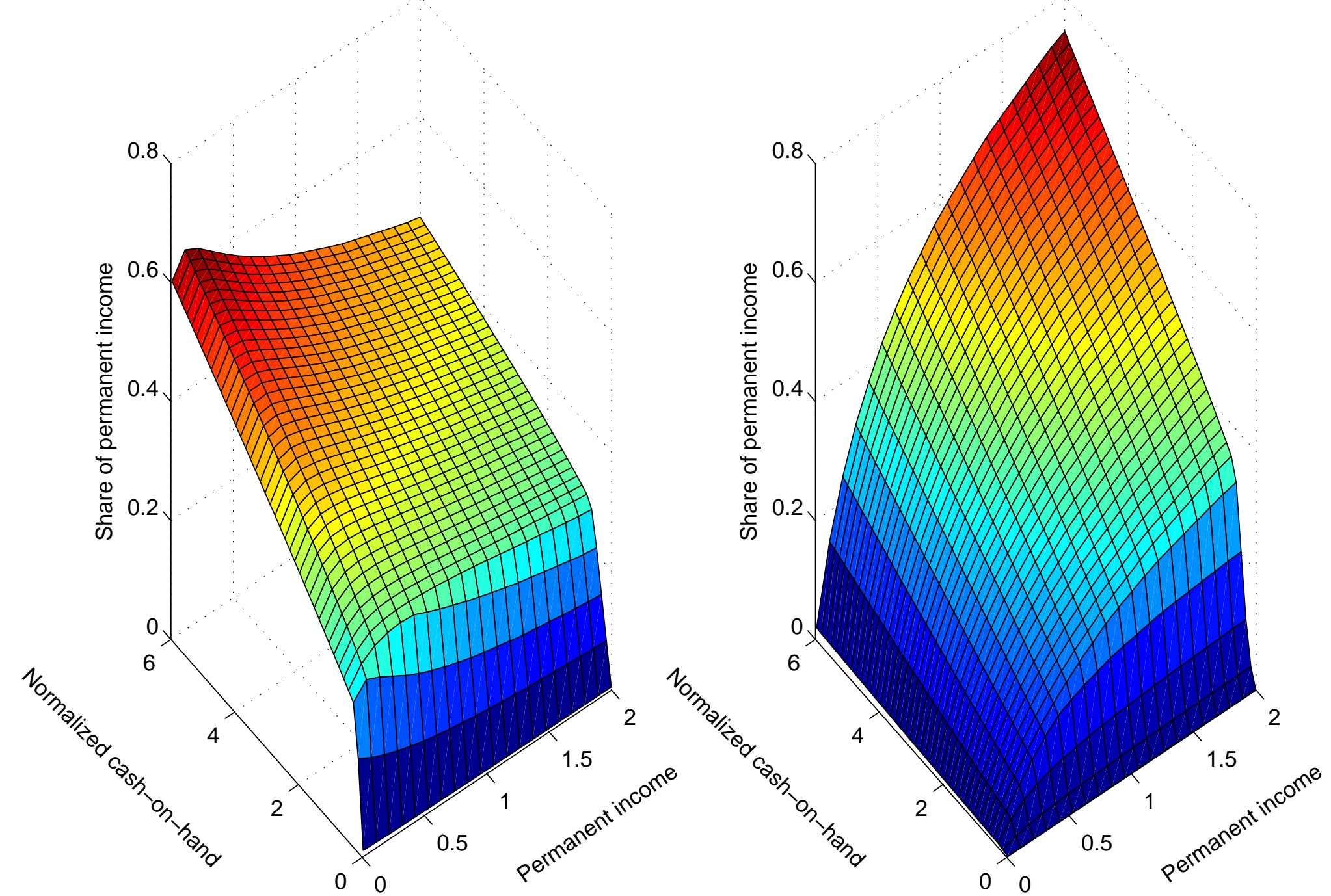

Figure 1: Optimal consumption policy in the nonhomothetic life-cycle model

The figure shows the optimal consumption policy at age 50 for a life-cycle consumption and portfolio-choice model with nonhomothetic utility. The policy variables are basic consumption $(b=B / P)$ and luxury consumption $(Q l=Q L / P)$, both expressed in units of basic consumption and normalized by permanent income. The state variables are normalized cash-on-hand $(w=W / P)$ and permanent income $(P)$. The household receives stochastic labor income from age 26 through 65 and retirement income from age 66 through 76 . Table 6 reports the preference and income parameters of the model. 


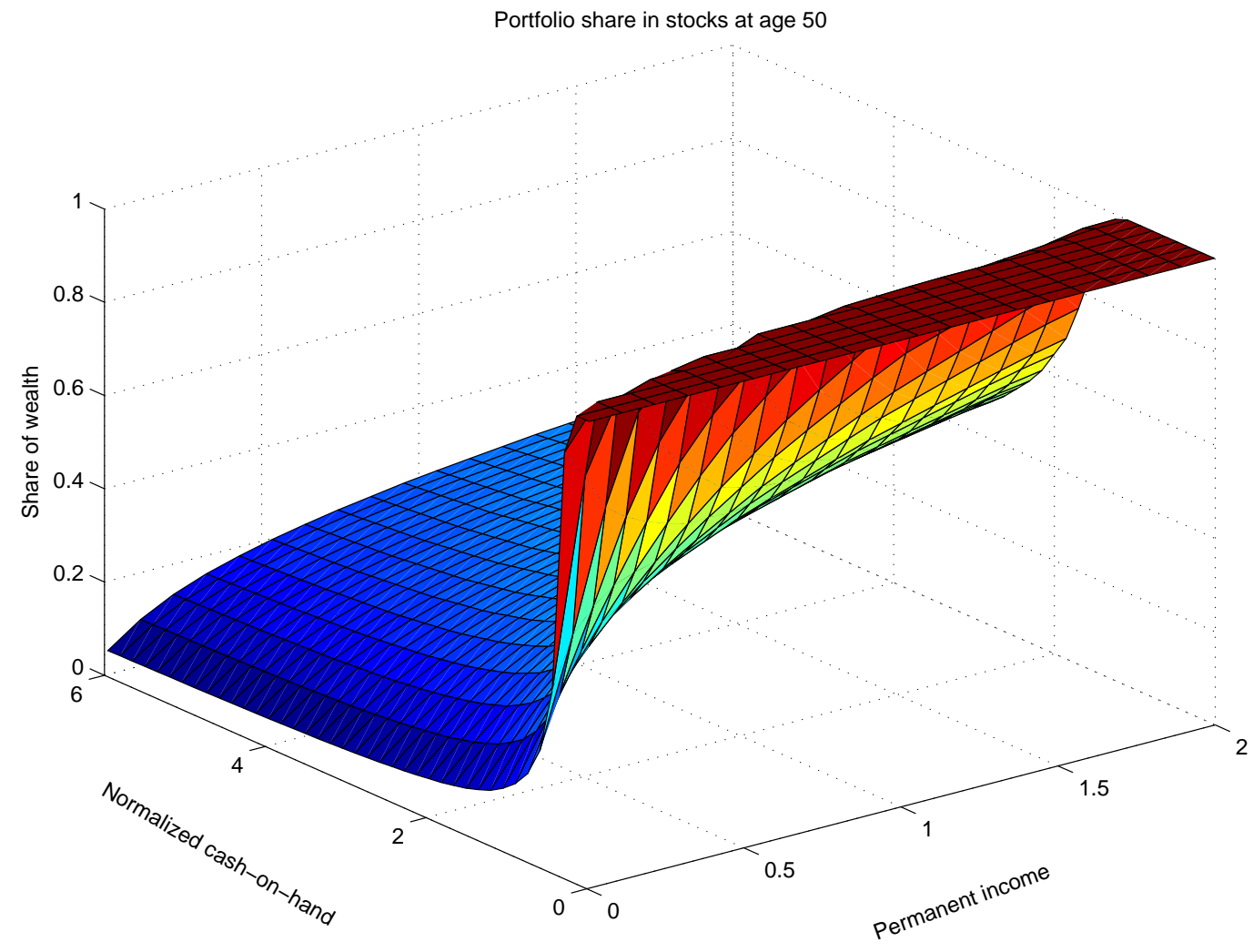

Figure 2: Optimal portfolio policy in the nonhomothetic life-cycle model

The figure shows the optimal portfolio policy at age 50 for a life-cycle consumption and portfolio-choice model with nonhomothetic utility. The policy variable is the portfolio share $(a)$. The state variables are normalized cash-on-hand $(w=W / P)$ and permanent income $(P)$. The household receives stochastic labor income from age 26 through 65 and retirement income from age 66 through 76. Table 6 reports the preference and income parameters of the model. 